\title{
Oxytocin Receptor Signaling in Vascular Function and Stroke
}

\author{
Erin C. McKay ${ }^{1,2 *}$ and Scott E. Counts ${ }^{1,2,3,4,5}$ \\ ${ }^{1}$ Department of Translational Neuroscience, Michigan State University, Grand Rapids, MI, United States, ${ }^{2}$ Neuroscience \\ Program, Michigan State University, East Lansing, MI, United States, ${ }^{3}$ Department of Family Medicine, Michigan State \\ University, Grand Rapids, MI, United States, ${ }^{4}$ Hauenstein Neurosciences Center, Mercy Health Saint Mary's Hospital, Grand \\ Rapids, MI, United States, ${ }^{5}$ Michigan Alzheimer's Disease Research Center, Ann Arbor, MI, United States
}

The oxytocin receptor (OXTR) is a G protein-coupled receptor with a diverse repertoire of intracellular signaling pathways, which are activated in response to binding oxytocin (OXT) and a similar nonapeptide, vasopressin. This review summarizes the cell and molecular biology of the OXTR and its downstream signaling cascades, particularly focusing on the vasoactive functions of OXTR signaling in humans and animal models, as well as the clinical applications of OXTR targeting cerebrovascular accidents.

Keywords: oxytocin receptor, oxytocin, cerebrovasculature, cognition, stroke

\section{OPEN ACCESS}

Edited by: Vincent Geenen,

University of Liège, Belgium

Reviewed by: Valery Grinevich,

German Cancer Research Center (DKFZ), Germany

Gareth Leng,

University of Edinburgh, United Kingdom

*Correspondence: Erin C. McKay

mckayer3@msu.edu

Specialty section: This article was submitted to

Neuroendocrine Science, a section of the journal

Frontiers in Neuroscience

Received: 22 June 2020

Accepted: 31 August 2020 Published: 25 September 2020

Citation:

McKay EC and Counts SE (2020) Oxytocin Receptor Signaling

in Vascular Function and Stroke.

Front. Neurosci. 14:574499.

doi: 10.3389/fnins.2020.574499

\section{INTRODUCTION}

Since its original cloning and characterization by Kimura et al. (1992), to more recent predictions of its three dimensional structure (Busnelli et al., 2016), the human oxytocin receptor (OXTR) has garnered special attention for its role as a potential therapeutic target in a wide array of physiological and behavioral disorders. Several recent reviews have comprehensively covered the impact of OXTR signaling upon peripheral and central control of behavior and physiological functions including osmoregulatory, stress modulation, and memory (Jurek and Neumann, 2018; Grinevich and Neumann, 2020). By contrast, this review will survey the role of OXTR-mediated cellular and molecular pathways regulating vascular function, with a special focus on mechanisms of cerebrovascular disease and the receptor's putative disease-modifying role in the post-stroke environment, which may be amenable to therapeutic targeting.

\section{THE OXYTOCIN RECEPTOR}

The OXTR is a widely expressed $\mathrm{G}_{\alpha \mathrm{q}}$ protein-coupled receptor (GPCR) that binds its endogenous nonapeptide ligand, oxytocin (OXT), with an affinity of about 1-10 nM (Chini et al., 2017), as well as a structurally similar nonapeptide, vasopressin, with an affinity of about $100 \mathrm{nM}-1 \mu \mathrm{M}$ (Postina et al., 1996). The OXT peptide and its full nine amino acid sequence was first detailed in 1953 by Du Vigneaud and colleagues through varied partial hydrolysis experiments combined with paper chromatography (du Vigneaud et al., 1953). However, its existence was recognized as early as 1928 when researchers began testing the effects of OXT from pituitary extracts on peripheral reactions such as uterine contractions and blood pressure (Bourne and Burn, 1928; Griling and Eddy, 1928; Gruber, 1928; Kamm et al., 1928). OXT has since been found to exert both central and peripheral effects via OXTR-mediated phospholipase C (PLC) activation and downstream $\mathrm{Ca}^{2+}$ signal transduction (Zingg and Laporte, 2003). OXT is synthesized in the hypothalamic magnocellular and parvocellular neurons, reaching the peripheral circulation through the posterior 
pituitary (Argiolas and Gessa, 1991), while central actions appear to occur through both axonal and possibly volume transmission through dendrites (Meyer-Lindenberg et al., 2011). This volume transmission and its relative contribution to OXTR activation is an ongoing subject of debate, as more OXT neuronal projections to forebrain OXTR-expressing regions have become apparent in recent years (Knobloch et al., 2012; Grinevich et al., 2016). The very first hint of a bioactive OXTR was indirectly demonstrated by Sir Henry Dale and focused on the induction of uterine contractions by posterior pituitary gland components (Viero et al., 2010). Since that time OXTRs have not only been identified in the uterus (Fuchs et al., 1984), but also the mammary glands (Soloff et al., 1977), heart (Gutkowska et al., 1997), blood vessels (Thibonnier et al., 1999b), and brain (Muhlethaler et al., 1983). While the presence and activity of the receptor in each of these regions underscores the importance of OXTR signaling in peripheral and central physiology, this review will focus primarily on those found in the brain. Regardless, the widespread expression of this receptor and its ligands underscores the continued relevance and necessity of research into its functional repertoire (Grinevich et al., 2016), even after the 100 years that have passed since Dale engaged the receptor without knowing what it was (Viero et al., 2010). Before turning to physiological and disease modifying possibilities for the receptor, its biology as revealed by basic research will be summarized. This section provides a synthesis of the current understanding of the OXTR gene and protein at the cellular level that will be necessary to fully grasp the potential of its therapeutic use.

\section{The Oxtr Gene}

In 1994, Inoue and colleagues described the genomic sequence of the human Oxtr, identifying it as a $\sim 17 \mathrm{~kb}$ single gene on chromosome 3 (Inoue et al., 1994). The gene contains two exons corresponding to the OXTR's promotor region and two exons corresponding to the receptor coding sequence itself, along with three introns of which the third displays the longest sequence at $12 \mathrm{~kb}$ (Gimpl and Fahrenholz, 2001). Three transcripts of varying lengths were found in uterine tissues and differences were observed in antibody binding to the third intracellular loop (Adan, 1995), suggesting the existence of receptor subtypes at the time. However, it is now recognized that the three mRNA transcript lengths are due to sequence differences in the untranslated region (UTR) flanking a single coding sequence, thus resulting in one receptor transcript that may be differentially regulated post-transcriptionally (Breton et al., 1996; Gimpl and Fahrenholz, 2001). The Oxtr gene promoter also contains multiple response element sequences that contribute to differential expression of the receptor across age (Vaidyanathan and Hammock, 2017), region (Boccia et al., 2013), and at parturition in females (Insel, 1990; Young et al., 1997). The promotor region of the receptor has three TGdinucleotide repeats that, based on the known ability of calcium to alter DNA structure at these repeats, could also explain some site-specific differences in OXTR mediated activity (Bale and Dorsa, 1997; Bale et al., 2001). Using kinase inhibitors, it has been demonstrated that regional differences exist in the brain as to whether protein kinase $\mathrm{A}$ or protein kinase
C leads to increased Oxtr gene transcription (Bale et al., 2001). The $5^{\prime}$-UTR and promoter region of the Oxtr also bears putative response elements to interleukin-6, acute-phase proteins, GATA-1, c-Myb, and activator proteins 1 and 2 (Inoue et al., 1994). Beyond the promotor region, interest has also alighted on potential regulatory elements in the large third intronic region that separates the amino acid coding exons. Mizumoto et al. (1997) reported a region of hypomethylation in a central part of the intronic sequence in highly expressing myometrium and hypermethylation in low expressing leukocytes, suggesting epigenetic regulation of the receptor gene within the third intron. Furthermore, experience and exposure-induced epigenetic regulation of the expression of the Oxtr has been studied in relation to the emergence of characteristics of several conditions including autism spectrum disorders (ASD) and psychiatric conditions such as schizophrenia (Gregory et al., 2009; Bang et al., 2019; Andari et al., 2020).

\section{Protein Structure}

Until recently, the tertiary structure of the OXTR had not been visualized with either X-ray crystallography or cryoEM but rather by computer simulations, perhaps owing to its conserved homology with the rhodopsin family GPCRs in general and the beta-adrenergic receptors in particular (Fanelli et al., 1999). Indeed, many studies have pointed to it being a prototypical Class A GPCR (Busnelli and Chini, 2018). In a potentially exciting development, a crystal structure obtained by Waltenspühl and colleagues was recently reported that supports a canonical GPCR topology (https://doi.org/10.1101/2020.02.21. 958090). This supports the rigor of prior structural studies of the OXTR, especially in the context of $\beta$-arrestin recruitment (Zhou et al., 2017) and dimerization (Busnelli et al., 2016), which have focused on comparisons to rhodopsin (Fanelli et al., 1999). The OXTR is composed of seven membrane-spanning $\alpha$-helices with three intracellular and extracellular loops, a $\mathrm{N}$-terminal region in the extracellular space, and a C-terminus in the cytoplasmic space (Barberis et al., 1998; Figure 1). Important individual structural elements of the OXTR, such as ligand binding sites, the site of interaction with the $G_{\alpha q}$ protein, transmembrane movements due to activation, and protein modifications have been revealed by computer simulation and mutation studies (Chini et al., 1995; Postina et al., 1996; Kimura et al., 1997; Barberis et al., 1998; Zhong et al., 2004; Busnelli et al., 2016; Zhou et al., 2017).

The OXTR binds both nonapeptides OXT and vasopressin, with OXT acting as a full agonist and vasopressin acting as a partial agonist (Chini et al., 1996). Of most relevance to this review is the similarity of vasopressin V1a receptors to OXTRs in structure, the $G$ proteins and kinases to which they couple, and the high concentration of these receptors in the CNS and vasculature (Zingg, 1996). The peptides are predicted to assume a similar shape at physiological $\mathrm{pH}$, consisting of a sixresidue ring with a three-residue linear region (Barberis et al., 1998). The binding pocket for the ligands most likely lies in a cleft surrounded by the transmembrane domains. Chini and colleagues used a coordinated method of ligand and receptor mutations to find residues on the first extracellular loop of the receptor and transmembrane domains V and VI that accounted 
A

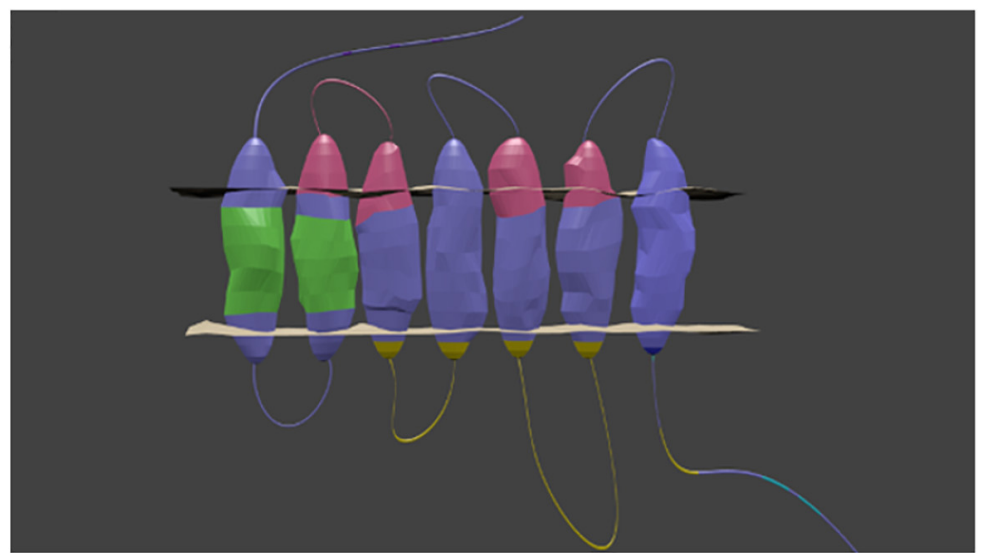

D

$\square$ Glycosylation sites
$\square$ Likely dimerization site
$\square$ Specifity for oxytocin
$\square$ Palmitoylation site
$\square$ G Protein binding
$\square$ B-arrestins binding

B

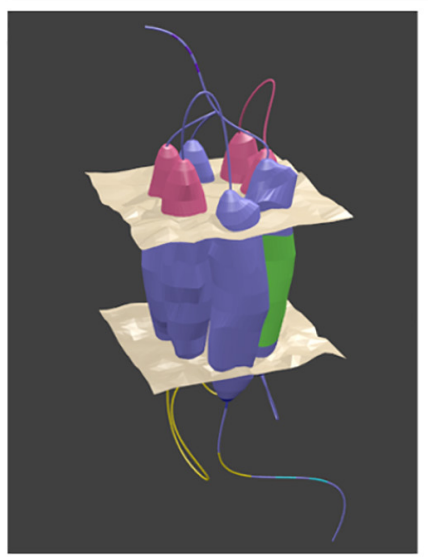

C

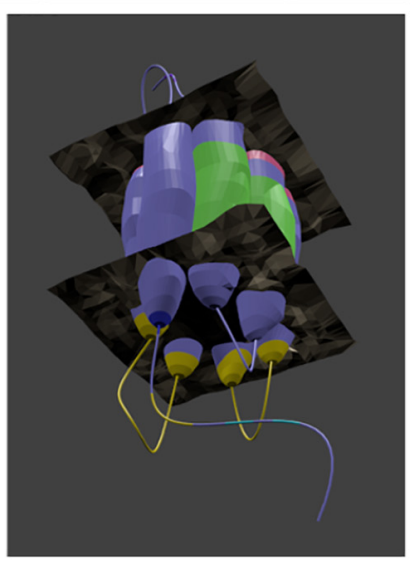

FIGURE 1 | Model of the oxytocin receptor A. (A) linear view of the receptor. (B) The top of the receptor as it forms a binding pocket. (C) The bottom of the receptor as it forms a binding pocket. (D) Color coded key. The general location of specialized sites are highlighted by color with key provided. Based on chimera, point mutation, and structural analysis studies as cited in the text. Created in Blender 2.8.

for the specificity of the receptor for OXT versus vasopressin (Mouillac et al., 1995; Chini et al., 1996). This occurs through aromatic-aromatic and hydrophobic-aromatic interactions with the isoleucine (I3) and leucine (L8) residues of OXT, which are the only two amino acids that differ between the two neuropeptides (Barberis et al., 1998). Therefore, any disruption in these residues would be expected to reduce the ability of the OXTR to respond to its natural agonist. The increase in availability of nonpeptide agonists and antagonists continue to contribute to the molecular modeling of this pore-based docking site, showing that its surface region promotes agonism and that deeper binding impairs conformational changes promoting antagonism (Uba et al., 2020). More broadly, the linear region of the peptide appears to closely interact with the first extracellular loop, and the cyclic region of OXTR appears to interact with the second extracellular loop with intermittent connectivity with transmembrane domains II-VII (Postina et al., 1996). A conserved aspartic acid residue in the second transmembrane domain (Asp 85) is demonstrably important for trafficking the OXTR to the plasma membrane (Schiffmann and Gimpl, 2018).

On the intracellular receptor face, research has focused on identifying the sites of $\mathrm{G}_{\alpha \mathrm{q}}$ protein subunit interactions, as well as the site of $\beta$-arrestin recruitment for receptor internalization.
Selective replacement of the intracellular loops shows that intracellular loops 2 and 3 are vital for the ability of the receptor to effect $G$ protein signaling, since no increase in phospholipase $\mathrm{C}$ is observed in their absence (Barberis et al., 1998). Furthermore, disruption of the large $\alpha$-helix within the fourth intracellular domain also subsequently disturbs the ability of the receptor to bind $\mathrm{G}_{\alpha \mathrm{q}}$ (Zhong et al., 2004). V1aRs also couple to $\mathrm{Gq} / 11$ proteins and stimulate calciumdependent signaling cascades (Zingg, 1996). The use of a X-ray free electron laser on crystalized rhodopsin in complex with arrestin revealed that phosphorylation at certain residues are vital to recruitment (Zhou et al., 2017). Briefly, the intracellular C-terminus of the receptor is phosphorylated at a $\beta$-sheet that attracts the N-terminus of arrestin, which allows it to undergo a conformational change or domain twist (Zhou et al., 2017). As such, a similar mechanism is likely to be involved in OXTR internalization and regulation of signaling activity. Additional OXTR posttranslational modifications include three $\mathrm{N}$-glycosylation sites at residues $\mathrm{N} 8, \mathrm{~N} 15$, and N26 in the $\mathrm{N}$-terminus and sites for palmitoylation at cysteine residues C346 and C347 in the C-terminus; however, so far no vital role for these modifications have been defined (van Kesteren et al., 1996; Kimura et al., 1997; Barberis et al., 1998). 
Recent GPCR research has revealed the ability of many GPCRs to dimerize or even oligomerize to maximize the strength of intracellular signaling (Cottet et al., 2010). Busnelli and colleagues recently demonstrated a likely presence of high affinity dimers of OXTR. Moreover, by using alkane spacers of varying lengths between ligands, they were able to identify a likely place of dimerization on the OXTR (Busnelli et al., 2016). The linkage probably occurs at the position of transmembrane helix 1 to transmembrane helix 2 which would accommodate bivalent ligands and allow for a reduction in entropy cost that would favor the formation of dimers (Busnelli et al., 2016). While methods need to advance before we can confirm the relative occurrence of single receptors, dimers, or oligomers, it provides an intriguing possibility for discrete manipulation of the OXT system, perhaps even for some of the conditions discussed below (Cottet et al., 2010). See Figure 1 for a visual summary.

\section{Signaling and Cellular Function}

As noted above, activation of the OXTR typically stimulates intracellular $\mathrm{Ca}^{2+}$ mobilization through a PLC-dependent mechanism (Park et al., 1998; Gutkowska and Jankowski, 2012). While the OXTR is reported as coupling predominantly to $\mathrm{G}_{\alpha \mathrm{q} / 11}$ type $\mathrm{G}$ protein subunits, it is now established that the OXTR also couples to $G_{i} / G_{0}$ type $G$ protein complexes (Hoare et al., 1999; Busnelli and Chini, 2018). Recently, an ambitious synthesis of previous reports of OXTR intracellular signaling pathways was completed by Chatterjee and colleagues. To date, this open-source resource on NetPath is the most comprehensive overview of the OXTR signaling cascade (Chatterjee et al., 2016). Several of the more well-established pathways and their functional role at the cellular level will be described below. $\mathrm{G}_{\mathrm{q} / 11^{-}}$ transduced signaling is mediated by PLC-stimulated hydrolysis of the phospholipid phosphatidylinositol 4,5-bisphosphate $\left(\mathrm{PIP}_{2}\right)$ to diacylglycerol (DAG), which in turns activates protein kinase $\mathrm{C}$ (PKC) and inositol 1,4,5-trisphosphate $\left(\mathrm{IP}_{3}\right)$, which stimulates the release of intracellular $\mathrm{Ca}^{2+}$ stores via $\mathrm{IP}_{3}$ receptors and also activates PKC among other $\mathrm{Ca}^{2+}$-activated kinases (Thibonnier et al., 1999a; Viero et al., 2010).

Phospholipase C stimulates the phosphorylation of PI3K and AKT leading to the activation of endothelial nitric oxide synthase (eNOS) influencing cellular migration and vasodilation (Cattaneo et al., 2009; Viero et al., 2010). Additionally, the involvement of Rho kinases in smooth muscle uterine contractions suggests that OXTR activation of these kinases can lead to the production of phospholipase A2 and, in turn, cyclooxygenase 2 (Viero et al., 2010). The modulation of levels of Rho GTPases by OXTR leads to shifts in cell adhesion molecules, particularly in neurons (Zatkova et al., 2019). OXTR-stimulated PKC signaling has been shown to lead to the dephosphorylation of eukaryotic translocation factor eEF2, which aids in cellular proliferation through peptide chain elongation (Devost et al., 2008). Several other kinases are reported to be activated through the $\mathrm{G}_{\alpha \mathrm{q} / 11}$ cascade of OXTR activation including the mitogenactivated protein kinases (MAPKs) ERK1/2, which induce c-fos and c-jun expression as an early mediator of proliferation, and ERK5, which is more specific to cellular differentiation (Zingg and Laporte, 2003; Devost et al., 2008). Whereas the suspected $G_{i} / G_{0}$ pathway is less well-defined, it has been demonstrated that $G_{i \beta \gamma}$ signaling leads to p38 MAPK activation and aids cells in adaptive processes to physiological stressors through transcriptional activators and direct effects on cell stabilizing proteins (Hoare et al., 1999). Potential hyperpolarizing effects through $\mathrm{G}_{i}$ could occur through interactions with $\mathrm{Ca}^{2+}$ dependent $\mathrm{K}^{+}$channels, as proposed based on recent studies using alternative peptides and chelators (Pierce et al., 2019). Hence, in addition to the well-established role for OXT as a contraction influencing hormone, it appears to be involved in cellular differentiation, migration, proliferation, responses to stressors, dilation, and inflammation.

The response to OXTR signaling varies in a cell typedependent manner (Figure 2). In smooth muscle cells and neurosecretory cells this results in contraction and excitability, respectively (Poulain and Wakerley, 1982; Soloff and Sweet, 1982). Importantly, smooth muscle cells respond to $\mathrm{Ca}^{2+}$ mobilization by triggering calmodulin to activate myosin-light chain kinase (Zingg and Laporte, 2003), most prominently at parturition leading to uterine contractions (Soloff et al., 1977). OXTR-secreting neurons of the hypothalamus express presynaptic OXTRs that are self-excitatory, which may impact the glutamatergic properties of subpopulations of these neurons (Hrabovszky and Liposits, 2008). Due at least partially to the neuromodulatory effect of OXT at OXTRs on neurons of multiple subtypes (Stoop, 2012), the general excitatory or inhibitory effects throughout the brain appears to differ and is further confounded by an influence on ionic channel expression (Bakos et al., 2018). For instance, it has excitatory effects at the hippocampal formation (Tiberiis et al., 1983), and presynaptic inhibitory effects in the SON (Hirasawa et al., 2001). Some studies have suggested an effect of OXTR activation on astrocytes including a modulation of glutamatergic signaling and GFAP induction that might be important for plasticity (Di Scala-Guenot and Strosser, 1992; Kuo et al., 2009; Wang and Hatton, 2009). Additional effects of OXTR signaling, whether stimulated by OXT or AVP, on CNS physiology and behavior will be discussed in greater detail below.

\section{Signaling Partners}

As a receptor with a divergent, context-dependent signaling cascade, OXTR activity is influenced by interactions with a variety of additional cell and tissue-specific signaling partners and modulators. Many of these OXT and vasopressin bindingindependent activities have involved a parallel expansion on the roles of known cellular components; among these are $\beta$-arrestins, cholesterol, and steroid hormones. Therefore, these connections have expanded not only our understanding of OXTR physiology, but also of GPCR-mediated cell biology.

Once thought to be only involved in the receptor desensitization process, the role of arrestins in receptor activation has recently been more fully elucidated. The $\beta$-arrestins have been suggested to promote alternative GPCR signaling pathways when ubiquitinated by sterically hindering interactions between the receptor and canonical pathway signaling partners and acting as a scaffold for enzymes driving alternative pathways (Shenoy and Lefkowitz, 2011). One such scaffolding activity that has been 


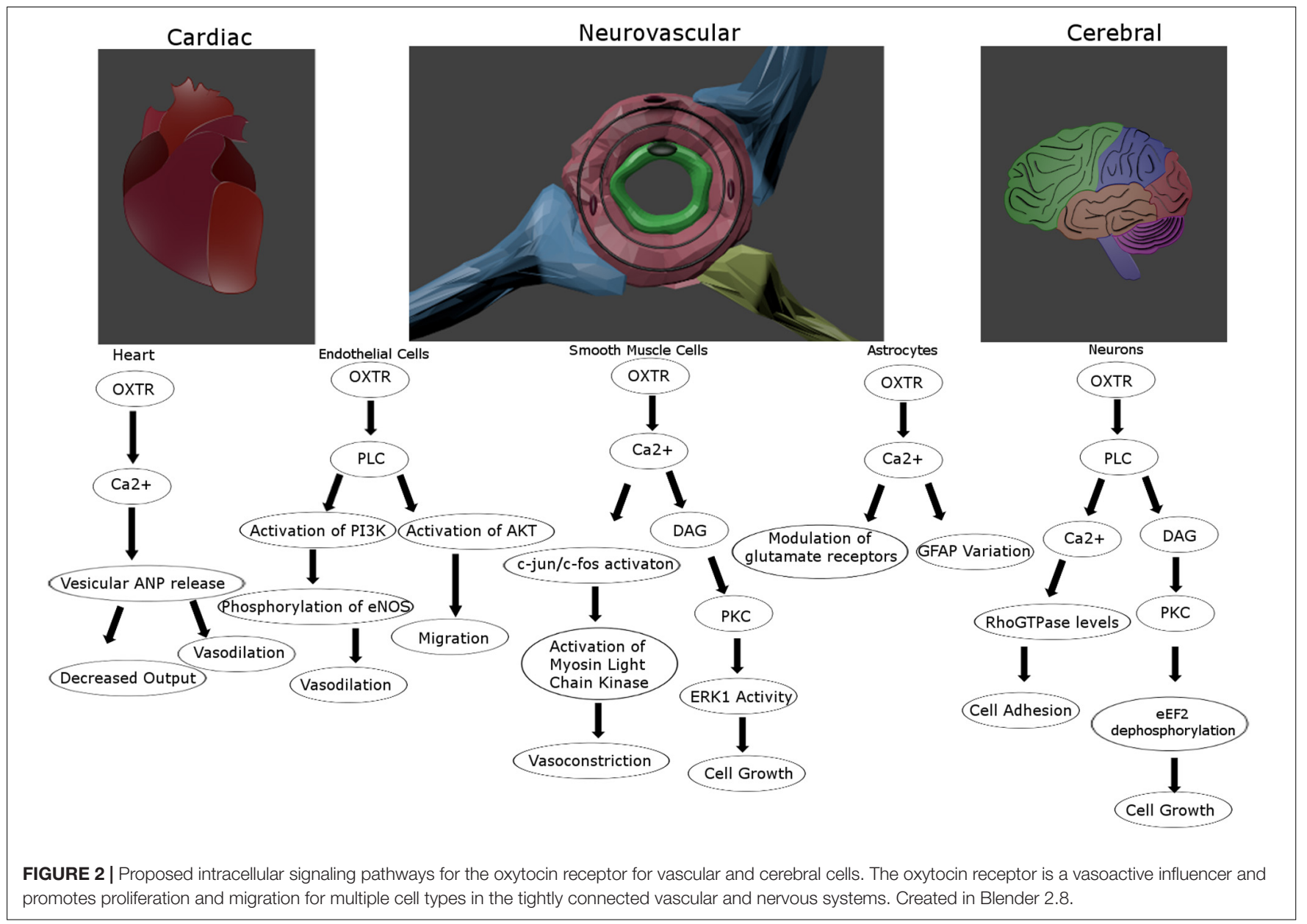

defined is the role of $\beta$-arrestin in recruiting cRAF-1, ERK2, and MEK1 to form the ERK2 signalosome, which can control nuclear transcription factors through phosphorylation (Luttrell et al., 2001). Another such $\beta$-arrestin role in signal transduction is its recruitment of the tyrosine kinase c-SRC for the purpose of mitogenic activity (Luttrell et al., 1999). While it is uncertain whether these pathways are also associated with the OXTR signaling repertoire, its known interactions with the $\beta$-arrestins suggest additional signal transduction properties initiated by internalized receptors.

Cholesterol is a lipoprotein long held to be an important building block of the plasma membrane, but GPCR research has also identified it as a potential factor in receptor activation. Work by Gimpl and colleagues identified a dual role for cholesterol in modulating OXTR signaling (Gimpl et al., 2002). When analyzing the role of varying cholesterol content on the binding of OXT to its receptor, they found a cooperative and facilitating role for cholesterol as an allosteric molecule for endogenous OXTR signaling (Gimpl et al., 2002). Specifically, chimeric approaches using the cholecystokinin type $\mathrm{B}$ receptor possessing a critical C-terminus region of the OXTR (amino acid residues C347A389) suggest that the binding site for multiple molecules of cholesterol is located on the N-terminus of the receptor (Gimpl et al., 2002) or alternatively, due to specific residues on transmembrane domains 5 and 6 (Politowska et al., 2001). Further debate on the location of the cholesterol binding site may arise with the publication of the crystal structure of the OXTR, which suggests it is located within a pocket of transmembrane domains 4 and 5 (https://doi.org/10.1101/ 2020.02.21.958090). Secondarily, they reported that cholesterol protected OXTRs from degradation under high heat conditions (Gimpl and Fahrenholz, 2000). Further allosteric molecules include $\mathrm{Mg}^{2+}$, which is a positive allosteric molecule (Antoni and Chadio, 1989), and $\mathrm{Na}^{2+}$, which lowers the affinity of OXTR for its ligand in a concentration dependent manner (Schiffmann and Gimpl, 2018).

Estrogen may also play an essential role in OXTR signaling. In the uterus, the OXTR increases in density around parturition and decreases swiftly afterward (Soloff and Sweet, 1982). This increase is believed to be the consequence of a surge in the concentration of estrogen, with subsequent decreases due to progesterone (Soloff and Sweet, 1982). Further, predictable variances have also been noted around the estrous cycle in rats when estrogen and progesterone levels vary (Van Tol et al., 1988). Experiments using the protein synthesis inhibitor cycloheximide bolstered the belief that estrogen-induced OXTR expression is de novo synthesis-dependent and its decline in expression is due to progesterone's antagonistic effect (Soloff and Sweet, 1982). In 
this regard, an estrogen response element (ERE) was found in the OXTR promoter region, and it has been reported that the addition of estrogen to the brain in pregnant rats resulted in increased OXTR expression in several brain regions (Young et al., 1997). Consistent with this, in vitro studies showed that cells transfected with the full palindromic ERE increased Oxtr promotor activity and increased protein levels, while a truncated ERE did not (Bale and Dorsa, 1997). Interesting, this effect of estrogen on Oxtr expression was not found in virgin dams, suggesting that additional factors associated with pregnancy synergize to upregulate the Oxtr gene (Young et al., 1997). While the complete story of steroid hormone influence on the OXTR remains to be elucidated, in vivo studies using mice deficient in estrogen receptor $\alpha$ (Young et al., 1998) suggest it is vital for OXTR increases due to estrogen. Studies of virally labeled OXTR in female ovariectomized rats with subsequent hormone replacement point to estrogens as potentially driving sexually dimorphic expression in certain regions where estrogen receptor $\alpha$ is co-expressed (Sharma et al., 2019). Also, in vitro binding studies suggest progesterone's inhibition of OXTR binding density is due to a direct interaction with the OXTR (Grazzini et al., 1998); however, progesterone's antagonistic effect toward estrogen also cannot be ignored (Soloff and Sweet, 1982).

\section{Cellular Processing}

Once recruited from the endoplasmic reticulum to the cell surface (Dong et al., 2007), it is believed that usually the OXTR undergoes endocytosis and recycling upon stimulation (Conti et al., 2009). In order to trace the dynamic processing of the OXTR throughout the cell, we will focus on the process of receptor desensitization, internalization, trafficking, and recruitment.

Desensitization is a very important process to protect and preserve GPCR signaling as it both protects the cell from overstimulation, while also allowing for the recycling of receptors back to the cell surface for multiple responses over time, a discovery based on early studies of $\beta$-adrenergic receptors (Shear et al., 1976; Benovic et al., 1987; Smith et al., 2006). Varying time frames have been estimated for peak desensitization of the OXTR upon agonist stimulation. A range of 4-6 h for peak desensitization has been reported in myocytes expressing OXTR (Robinson et al., 2003), while others have reported it taking up to $20 \mathrm{~h}$ (Phaneuf et al., 1997). These differences can mostly be attributed to the concentration and tissue dependent aspects of receptor desensitization (Plested and Bernal, 2001).

Oxytocin receptor is considered a Class A GPCR with respect to its interaction with $\beta$-arrestins, meaning that it maintains a strong connection with $\beta$-arrestin to regulate its endocytosis into secretory or degradative pathways (Conti et al., 2009). The interaction of OXTR with $\beta$-arrestins, and therefore its desensitization, is initiated by phosphorylation of the receptor by $\mathrm{G}$ protein receptor kinase 6 (Grotegut et al., 2016, 2017). Studies on OXTR tagged with GFP suggest that many receptors are recycled back though the secretory pathway, indicating a more sustained need for OXTR pathway signaling. Indeed, fluorescence microscopy studies revealed the colocalization of fluorescently tagged OXTR with transferrin after stimulation and a subsequent return of the signal to the plasma membrane $4 \mathrm{~h}$ later independent of protein synthesis, suggesting prominent receptor recycling (Conti et al., 2009). Further detection of OXTR co-labeling with Rab5 and Rab4, small GTPases involved in "short cycle" trafficking back to the membrane, also support this conclusion (Conti et al., 2009). While this may be the typical cycle, this is not always the case, as $\beta$-arrestin-independent internalization and recycling loss has also been reported, particular with analogs of OXT (Passoni et al., 2016). Some nuclear trafficking of the OXTR in concert with $\beta$-arrestins, Rab5, importin- $\beta$, and transportin- 1 has been reported in mouse osteoblasts, but any transcription modifying effects remain speculative (Di Benedetto et al., 2014).

Comparatively less is known about the trafficking of the receptor to the plasma membrane post-translation. Three $\mathrm{N}$-linked glycosylation sites within the N-terminus of the OXTR suggest the importance of cell surface targeting of the receptor for cell function, although whether these sites are used for such a role is disputable (Kimura et al., 1997). As mentioned above, when the conserved residue Asp 85 is mutated in the OXTR, very little receptor makes it to the plasma membrane post-translation, suggesting a vital role for this amino acid in some stage of trafficking (Schiffmann and Gimpl, 2018). It is also unclear which Rab GTPases are involved in the initial trafficking from ER to Golgi to plasma membrane after translation (Dong et al., 2007). Given the established role the secretory pathway plays in controlling the number of receptors available at the cell surface, and therefore signaling magnitude (Dong et al., 2007), further research into OXTR trafficking dynamics will shed insights into its potential multifactorial role in cell and tissue function. Possible variances in desensitization and trafficking of the OXTR could have therapeutic implications based on drugs and individual differences, such as the divergence in pathways by different agonists (e.g., carbetocin vs. OXT) (Passoni et al., 2016). These variables may impact our understanding for OXTR-mediated functions with respect to vascular health, as discussed below.

\section{OXTR SIGNALING IN VASCULAR HEALTH AND DISEASE}

\section{Vasoactive Agent}

OXTR-regulated vasogenic activity has been well established from the earliest use of its peptide ligand in research (Gruber, 1928), when OXT was observed to lower blood pressure. This long-term decrease in blood pressure has subsequently been confirmed in rats (Petersson et al., 1996) and humans (Light et al., 2005). Subsequent studies in pregnant women and rats have shown that while blood pressure drops, heart rate increases with peripheral administration of OXT (Yashpal et al., 1987; Rabow et al., 2018). The interest in OXTR as a candidate in the etiology of and treatment for cardiovascular conditions has recently been revived due in large part to the work of Gutkowska and Jankowski (2012), which supports the concept of a protective effect for OXTR signaling in tissue response to infarctions that will be detailed below.

Oxytocin receptors are localized in the heart contributing to the release of atrial natriuretic peptide (ANP) and a decrease 
in cardiac output (Figure 2; Gutkowska et al., 1997). OXT can induce vasodilation when acting on endothelial cells through eNOS activation (Uvnäs-Moberg, 1998; Thibonnier et al., 1999b), but can also promote vasoconstriction when acting on smooth muscle cells (Altura and Altura, 1984; Figure 2). Further, there is reason to believe this might not be due to OXTR signaling, but through OXT acting on vasopressin receptors (Suzuki et al., 1992; Oyama et al., 1993). These divergent findings might also be vessel-dependent, as small artery vasodilation upon OXT administration has been reported (Rabow et al., 2018), while larger peripheral arteries may respond instead with vasoconstriction (Petersson, 2002). As Petersson points out, this could be explained by the alternate effects of OXTR activation upon endothelial versus smooth muscle cells, their relative distribution in large and small vessels, and the administration method (Petersson, 2002). OXTRs in the cerebrovasculature seem to maintain many of the same attributes as central receptors such as upregulation following circulating estrogen (Gutkowska et al., 2000), and interactions with arrestins and the same G proteins (Gutkowska and Jankowski, 2012). However, the blood pressure lowering effects of OXT seems to be based on receptors in the periphery and not those in the CNS, as peripherally but not centrally administered OXT lowers blood pressure (Petersson et al., 1998). A systemic rise in OXT concentration, even with intranasal delivery, leads to a decrease in regional cerebral blood flow, primarily in the amygdala (Martins et al., 2020). Alternatively, this same route of delivery under an fMRI using cerebral blood volume reported an increase in the hippocampus and frontal cortex (Galbusera et al., 2017). Although vasopressin can also activate OXTR receptors at high concentrations, vasoconstriction and increased heart rate via central administration of vasopressin is thought to be mediated by V1a receptors (Ohlstein and Berkowitz, 1986; Faraci, 1989; Loziæ et al., 2018). Hence, the cross reactivity between these ligands and receptors do seem to be independently distinguishable, and OXTR signaling clearly influences vascular activity in a context-dependent manner.

\section{Oxidative and Inflammatory Stress}

Oxidative stress and inflammation are common to many neurodegenerating conditions, including those induced by an ischemic injury (Shukla et al., 2011; Chitnis and Weiner, 2017). An increase in antioxidant enzymes, activation of reactive oxygen species (ROS) producing enzymes, or decreased ROS directly are taken as evidence of a potential protective effect (Weber et al., 2008; Kahles and Brandes, 2012). Levels of pro- and anti-inflammatory cytokines as well as upstream activators are a means of identifying if there is evidence for inflammatory modulation (Barone and Parsons, 2000; Li X. et al., 2017). There is evidence from in vitro and in vivo studies that signaling through OXTR influences antioxidant and antiinflammatory outcomes.

In vitro studies have shown that exogenously applied OXT decreases the production of reactive oxygen species (ROS) initiated by $\mathrm{H}_{2} \mathrm{O}_{2}$ application to lymphocytes (Staniæ et al., 2016). This observation is supported by in vivo studies finding reduced ROS production with chronic OXT treatment in a mouse model of ASD (Wang et al., 2018) as well as reduced oxidative stress status in OXT-treated naïve Wistar rats (Honceriu et al., 2016), ischemia-reperfused Sprague-Dawley rats (Faghihi et al., 2012), and naïve zebrafish (Balmus et al., 2017). Candidate downstream enzymes mediating OXT's effects on ROS production include MAPK/ERK1/2, superoxide dismutase (SOD), and glutathione as antioxidant promoting pathways (Deing et al., 2013; Polshekan et al., 2016; Wang et al., 2018). Moreover, NADPH oxidase-mediated production of ROS is observed to be dampened with the addition of OXT, indicating an effect of attenuating prooxidative pathways (Szeto et al., 2008; Rashed et al., 2011). Alternatively, OXTR knockdown in fibroblasts led to a decrease in oxidative stress and an increase in antioxidative enzymes (Deing et al., 2013). Critically, in a parallel but inverse set of discoveries, the use of OXTR antagonists lead to an increase in markers of oxidative stress in cardiac tissue (Simsek et al., 2012). In cardiac cells and in vivo rat hearts a protective effect for vasopressin, and specifically vasopressin acting at $\mathrm{V} 1 \mathrm{aR}$ and OXTRs has been reported to reduce oxidative stress (Nazari et al., 2015; Ghorbanzadeh et al., 2020). So in regard to OXT and OXTR roles in oxidative stress, complete independence from the arginine-vasopressin system cannot be assumed. While the bulk of the evidence available points to a decrease in ROS following OXT administration or OXTR engagement, it is unclear whether encouraging antioxidative signals is the primary cause or a reduction in prooxidative ones, and whether enzymatic subtypes, cell type, or injury state matter.

With respect to the role of OXTR signaling in inflammatory modulation, complementary in vitro and in vivo studies have shown that OXT administration reduces the production of proinflammatory cytokines such as IL-6, TNF- $\alpha$, and IL-1 $\beta$ (Szeto et al., 2008; Jankowski et al., 2010; Garrido-Urbani et al., 2018), and increases anti-inflammatory cytokines such as IL-10 and TGF- $\beta$ (Jankowski et al., 2010; An et al., 2019). This dampening of proinflammatory cytokines is at least partially attributed to actions at NF-k $\beta$ (Yuan et al., 2016). Alternatively, stimulating the OXTR leads to a several fold reduction in the receptor for advanced glycation end-products (RAGE), which stimulates macrophage cells to produce proinflammatory cytokines (Metz et al., 2012). Additionally, cytokines like IL-6 and IL-1 $\beta$ appear to feed forward and increase the expression of OXTR (Young et al., 1997; Schmid et al., 2001), suggesting a protective feedback loop. While less studied than OXT, the role of vasopressin in inflammation is highly variant in either enhancing or dampening inflammatory responses and this could be due to multiple receptor subtypes (Ameli et al., 2014; Jan et al., 2017; Xu et al., 2017). However, as far as specific inflammatory cell types, OXT seems to generally promote the activation of peripheral immune responses while tempering central immune activation ( $\mathrm{Li} \mathrm{T}$. et al., 2017; Stary et al., 2019). For instance, OXT increases the production of spleen leukocytes, enhances the differentiation of thymus immune cells (Hansenne et al., 2005; Stary et al., 2019), and reduces inflammation-related transendothelial cell migration (Erkanli et al., 2013; Liu et al., 2017), whereas OXT appears to mitigate microglial activation in the brain (Yuan et al., 2016; Inoue et al., 2019; Mairesse et al., 2019). The elucidation of the full 
extent of OXTR signaling involved immune activation and the consequences of this activation on OXTR activity is an ongoing subject of research.

\section{The OXTR in Brain: Cerebrovascular Function and Post-Stroke Potential}

The potential role for OXTR signaling in cerebrovascular protection is grounded in evidence for its protective role in the periphery. With respect to cardiovascular disease, OXTR stimulation in the heart causes the release of ANP and decreased heart rate (Gutkowska et al., 1997). In addition, a decrease in pressure in the chambers of OXT-treated hearts has also been reported (Costa-E-Sousa et al., 2005). Stress-induced increases in blood pressure that can prove deleterious over time are also mitigated with higher plasma OXT in mothers (Grewen and Light, 2011). Since ischemic heart disease is a leading cause of death worldwide (Naghavi et al., 2015), the idea that OXTRmediated effects might prove effective as a management strategy or as an acute rescue agent has gained traction (Nilsson, 2009). OXT treatment in rodents has been shown to induce stem cells to adopt a cardiomyocyte phenotype (Matsuura et al., 2004), which could lead to exciting prospects in cardiac regeneration. Some experiments have even tested non-invasive ways to increase OXT after heart surgery, including massage and music interventions (Nilsson, 2009). In addition to these acute treatments, long term OXT increases are thought to be a primary agent through which social ties reduce the risk for cardiovascular disease (Knox and Uvnäs-Moberg, 1998). In rats, treatment with OXT lowered blood pressure in a hypertensive strain (Petersson and Uvnäs-Moberg, 2008), and prevented the occurrence of hypertension subsequent to hypoxic injury (Jameson et al., 2016), whereas hypertension induced by angiotensin-II was found to be exacerbated by OXT administration (Phie et al., 2015). In regards to cardiac sympathetic tone, one study examining myocardial infarction found a negative effect of OXT based increased sympathetic tone (Roy et al., 2018), while another examining ventricular hypertrophy and subsequent heart failure found a beneficial effect to this same OXT linked sympathetic tone based modulation (Garrott et al., 2017). This is an interesting paradox that could perhaps suggest a strong environmental effect to the effects of OXT. It could be that the response to OXT in an ischemic environment versus one of pathological remodeling could differ substantially. Regardless, well-controlled longitudinal studies are needed to assess whether OXTR manipulation might lead to improved cardiovascular or even cerebrovascular outcomes.

Oxytocin receptors might be uniquely positioned to respond to vascular insults due to their localization on microvascular endothelial cells (Thibonnier et al., 1999b; Nakamura et al., 2000). OXT has been shown to induce proliferation of endothelial cells, most likely through a PI3K and Src kinase dependent production of nitric oxide by eNOS (Cassoni, 2006; Cattaneo et al., 2008). Beyond these pro-angiogenic effects, the receptor appears to have potent anti-inflammatory and antioxidant properties. It both reduces the activity of NADPH oxidase isoforms on endothelial cells and innate immune cells (Szeto et al., 2008; Rashed et al.,
2011) and reduces the production of pro-inflammatory cytokines in favor of anti-inflammatory cytokines (Jankowski et al., 2010; Wang et al., 2018). OXTRs also potentiate the uptake of glucose during hypoxia (Lee et al., 2008; Florian et al., 2010).

Notably, these are some of the same pathways that are thought to be beneficial in the recovery of surviving tissue after an ischemic injury (Ooboshi et al., 2005; Bir et al., 2012; Liu et al., 2013; Rodrigo et al., 2013; Choi et al., 2015). OXTR activation has been mechanistically linked to the amelioration of tissue damage following cardiac infarction (Jankowski et al., 2010), renal infarction (Tuğtepe et al., 2007), hepatic infarction (Düşünceli et al., 2008), and cerebral stroke (Karelina et al., 2012; Moghadam et al., 2018; Seo et al., 2018). Cardiomyocytes can also be protected from ischemia and reperfusion injury through a reduction in mitochondrial-sourced ROS and a shift in cell signaling away from pro-apoptotic Bax toward antiapoptotic Bcl-2 (Gonzalez-Reyes et al., 2015). In examining cerebral ischemic stroke more directly, Karelina and colleagues (Karelina et al., 2012) used social housing, OXT treatment, and OXTR antagonists to demonstrate a protective role for OXT in reducing tissue loss and deleterious inflammation while enhancing antioxidative enzyme expression following middle cerebral artery occlusion. This observation has been extended to show that the neuroprotective effect of nursing in cerebral ischemia can be mimicked with exogenous OXT administration in mice, reducing ROS production and apoptotic neuron death (Moghadam et al., 2018; Stary et al., 2019). Effects on cognitive changes post-stroke in animal models and human studies are limited. Only one human case study poststroke has been published, wherein the authors speculated that a patient's rapid recovery from post-partum stroke may have been due to OXT administered to reduce postpartum bleeding and increased endogenous OXT release upon contact with her newborn (Seo et al., 2018). Cognitive effects have been limited to post-stroke depression and anxiety-like behavior in animals, and supposition in humans (Long and Hillis, 2016; Zhong et al., 2020). Post-stroke memory impairments are a relatively unexplored target.

In this regard, a de novo up-regulation of OXTRs in astroglia within the peri-infarct space was demonstrated in patients who died with a clinical pathologic diagnosis of vascular dementia, suggesting a druggable target for quick intervention (McKay et al., 2019). This is supportive of the detection of functional OXTR on astroglial cells in culture that can bind appropriate radioligands and trigger a release of TGF- $\beta$ (Di Scala-Guenot and Strosser, 1992; Mittaud et al., 2002), as well as reports of post-ischemic increases in OXTR for CNS tissue (Moghadam et al., 2018), though the opposite has been found in postischemic heart tissue (Jankowski et al., 2010). In cases of birth-related ischemic injury, OXT administration improved viability of immature hippocampal cells and reduced markers of oxidative stress (Tyzio et al., 2006; Ceanga et al., 2010; Kaneko et al., 2016), which may be linked to associated changes in GABAergic chlorine channels in addition to possible hemodynamic alterations (Tyzio et al., 2006; Kaneko et al., 2016). By contrast, other studies have found that OXT administered to dams of pups undergoing birth-related ischemic injury might 
actually exacerbate injury due to a vasodilatory reaction leading to exacerbated birth anoxia (Boksa et al., 2015). Critically, an ischemic environment might switch the vasodilatory effect of OXT to a vasoconstrictive one based on studies of isolated cerebral arterioles (Bari et al., 1997). In the case of long term management of vascular health, OXT has been found to reduce atherosclerosis in mice, rabbits and rats prone to the development of such plaques (Nation et al., 2010; Ahmed and Elosaily, 2011; Szeto et al., 2013). Interestingly, vasopressin might be protective against ischemic injury (Nazari et al., 2015), but V1aRs are thought to be deleterious and their antagonism may present a route of intervention (Ameli et al., 2014). While this work suggests that the OXTR is a valid target for recovery of cerebrovascular insults, including stroke related to cognitive impairment and dementia (McKay et al., 2019), further mechanistic and validation studies are warranted, especially in reference to ischemic conditions.

\section{Cell Survival}

Another current strategy to improve outcomes post-ischemia is the enhancement of cell survival through inhibiting apoptosis (Caglayan et al., 2019; Chen et al., 2020; Jia et al., 2020), reducing excitotoxicity (Maiolino et al., 2019; Jia et al., 2020), and improving metabolism (Ren et al., 2008). The general measures of reduced apoptosis are taken as a reduction in caspase activation and a higher ratio of $\mathrm{Bcl}$ 2 to Bax (Chen et al., 2020; Jia et al., 2020). Combatting excitotoxicity often ultimately focuses either on reducing glutamate signaling, mostly through NMDA receptors, or reducing intracellular calcium accumulation and waves in connected cells (Maiolino et al., 2019; Pietrogrande et al., 2019). The improvement of metabolism is closely tied to glucose uptake to sustain cells in the absence of production (Ren et al., 2008). While current methods to enhance cell survival through these means include pharmacological intervention, pre-conditioning, and non-invasive neuronal stimulation, there is reason to believe that enhancement of cell survival in post-ischemic environment could also be enhanced through targeting of the OXTR as evidenced by overlap with the survival mechanisms targeted in these studies. Some of these mechanisms include the favoring of anti-apoptotic proteins over pro-apoptotic ones, potential suppression of NMDA receptor activation, and the enhancement of glucose uptake in some cell types.

Oxytocin treatment increases the expression of the prosurvival Bcl-2 in cases of ischemia/reperfusion injury, at least in cardiac tissue (Kobayashi et al., 2009; Alizadeh et al., 2012). A reduction in the pro-apoptotic Caspase- 3 and Bax also supports the anti-apoptotic function of OXTR signaling (Erkanli Senturk et al., 2013; Erbas et al., 2017). Oxytocin administration dampens the basal levels of glutamatergic excitatory activity in the frontal cortex of mice, and the use of inhibitors suggests this occurs at the NMDA receptors (Ninan, 2011). Lastly, OXT administration enhances the uptake of glucose both peripherally in skeletal and cardiac cells (Lee et al., 2008; Florian et al., 2010), and centrally in non-human primates after intranasal administration (Arias del
Razo et al., 2020). Another option is, again, the observed prosurvival and glucose metabolism supporting effects as evidenced by vasopressin administration and V1aR knockout animals (Aoyagi et al., 2007; Ghorbanzadeh et al., 2020). While the existing evidence is minimal, and little has been tested centrally, there are reports of some enhancement of cell survival, including under ischemic conditions, for OXT and OXTR signaling.

\section{Synaptic Plasticity and Neurogenesis}

When it comes to CNS repair after injury, enhancing plasticity for the strengthening of remaining connections and neurogenesis for recovery are strong areas of focus (Onodera et al., 1990; Ohira et al., 2010; Nazari et al., 2016; Kisoh et al., 2017). The support of plasticity is assessed through the activation of kinases involved in the induction of long-term potentiation (LTP) and the modulation of synaptic receptors. Of the kinases involved in LTP studied in ischemic stroke the mitogen-activated protein kinases (MAPKs) are often cited (Davis and Vanhoutte, 2000; Komiyama et al., 2002), and the synaptic receptors like $\mathrm{GABA}_{\mathrm{A}}$ Rs (Clarkson et al., 2010; Kim et al., 2014). Neurogenesis in stroke studies is assessed both directly through markers like BrdU (Bartley et al., 2005), or through the production of growth factors (Naylor et al., 2005). Studies of OXT and the OXTR signaling pathways have revealed effects on plasticity and neurogenesis both in and outside of ischemic conditions. By contrast, vasopressin exerts little effect on neurogenesis outside of early development (Leuner et al., 2012), but an enhancement of plasticity in hippocampal subfields has been reported (Wang et al., 2001; Pagani et al., 2015).

Signaling cascades through the OXTR have been associated strongly with MAPKs, particularly ERK1/2 and ERK5 (Devost et al., 2008). The signaling of OXTR through these mechanisms are strongly associated with cellular proliferation (Tom and Assinder, 2010). Importantly, in hippocampal fields, a common site for the investigation of LTP, a facilitation of LTP by OXTR has been demonstrated to be dependent on MAPKs (Tomizawa et al., 2003; Lee et al., 2015). An important caveat to consider is the potential divergent effects of these signaling partners based on the cellular localization of receptors, namely whether they are present in caveolin domains or not (Guzzi et al., 2002; Rimoldi et al., 2003). From the time of its role in the GABAergic switch to an inhibitory one around birth, OXT is tied to GABAergic modulation (Tyzio et al., 2006). Now there is increasing interest in the OXT mediation of $\mathrm{GABA}_{\mathrm{A}} \mathrm{R}$ signaling, particularly under ischemic stress (Kaneko et al., 2016). While the protective effects observed have been attributed to a counter to excitotoxicity (Kaneko et al., 2016), the role of $\mathrm{GABA}_{\mathrm{A}}$ Rs, especially reducing tonic inhibition of these receptors, in enhancing neuroplasticity is an intriguing alternative (Clarkson et al., 2010).

In regards to neurogenesis, OXTR positive neurons in the CA2 and CA3 subfields of the hippocampus undergo neurogenesis as detected by BrdU upon OXT stimulation, while the deletion of the receptor impairs survival (Lin et al., 2017). A similar effect is found in the hypothalamus, while an opposite effect is observed in the olfactory bulb upon OXT stimulation (Lévy et al., 2019). Differences in effects within regions of the dentate gyrus are also observed as well (Leuner et al., 
2012). This suggests that the role of OXT and OXTR signaling in neurogenesis could be context dependent. Two potential effectors for this neurogenesis through OXTR signaling could be through Akt/PI3K signaling, which is tied to neurogenesis (BruelJungerman et al., 2009; Zhang et al., 2009) and or through support of growth factors cited as determinants of neurogenesis and angiogenesis (Dempsey and Kalluri, 2007). One avenue of OXTR signaling is through phosphorylation and activation of Akt/PI3K (Gonzalez-Reyes et al., 2015). Several growth factors appear to be upregulated upon OXT stimulation such as brain-derived neurotrophic factor and insulin-like growth factor (Sirotkin et al., 1996; Havranek et al., 2015). In turn, OXT and OXTR expression is regulated by growth factors, especially insulin-like growth factor 1 (Holtorf et al., 1989). While the interactions are complex and likely conditionally dependent there is reason to investigate OXTR signaling as an influencer of neurogenesis and plasticity.

\section{THE OXTR AS A THERAPEUTIC TARGET FOR ISCHEMIC INJURY}

Oxytocin receptor signaling has long been exploited for therapeutic purposes, such as for inducing labor or halting preterm contractions, but its potential clinical applications might go far beyond that. For example, as discussed above, there might be CNS applications for OXTR signaling in ameliorating CVD related tissue loss, enhancing repair, and/or protecting cognition. However, this goal is hindered by the inability of current agonists and antagonists to cross the blood brain barrier (BBB) and the lack of specific compounds that do not also target vasopressin receptors. Despite these hindrances, the history of successfully targeting GPCRs, which represent the majority of drug targets (Sriram and Insel, 2018), and the well-established safety profile of OXT (Anagnostou et al., 2014; DeMayo et al., 2017). suggests that there is translational potential in targeting the OXTR for vascular disease.

As a GPCR, the OXTR is a member of a class of the most widely utilized therapeutic targets, as 35\% of drugs on the market target GPCRs (Sriram and Insel, 2018). On the other hand, several hindrances have emerged that have slowed clinical and basic research aimed at targeting the OXTR. For example, endogenous OXT does not cross the BBB in large amounts, making central actions of the receptor difficult to manipulate (Mens et al., 1983). Additionally, many OXTR agonists or antagonists are not specific as they also show cross-reactivity with vasopressin receptors (Manning et al., 2012). Finally, disparate findings over the relative efficacy of peptide vs. non-peptide agonists for OXTR targeting have added a layer of complexity to development of novel therapeutic strategies (Evans et al., 1992; Freidinger and Pettibone, 1997; Manning et al., 2012). These challenges need to be overcome to truly test the extent to which OXTR signaling might modify the progression of cerebrovascular lesion spread, possible cognitive dysfunction, and/or additional functional impairments.

The BBB is relatively impenetrable except for gaseous and small molecules, especially to larger peptides or transmitters, though transporters exist to allow the gated passage of many other substances such as nutrients (Abbott et al., 2006; Daneman and Prat, 2015). Some studies have suggested that labeled OXT does cross the $\mathrm{BBB}$, but comparisons of methods and results reveal that about 1 in 10,000 units of peripherally administered OXT reaches the CNS (Mens et al., 1983; Hollander et al., 2003). A recent finding by Yamamoto and colleagues that RAGE on vascular endothelial cells is the main transporter responsible for this CNS bioavailability presents an enticing possible means to enhance this penetrance (Yamamoto et al., 2019). Though, the issues with targeting such a pro-inflammatory receptor as RAGE raises multiple troubling caveats (Wautier et al., 2017). Similar problems arise with the administration of intranasal OXT, as some studies have found beneficial effects when the peptide is administered in this way (Alvares et al., 2010; Goodin et al., 2014), but again, CNS penetration is relatively low (Leng and Ludwig, 2016). For a hormone with known peripheral and central properties, delivering supraphysiological doses to the periphery to ensure central activation likely results in off-target effects. Perhaps this concern is not such a hindrance, as MacDonald and colleagues found a serviceable safety profile with the use of up to 40 IU OXT (MacDonald et al., 2011). The reported side effects were extremely rare, with the only severe side effect being water intoxication reported twice among over 1500 cases (MacDonald et al., 2011). A promising alternative is the use of aerosolized OXT that, like intranasal oxytocin, relies on the nasal epithelium for absorbance, but can cover relatively more of the surface (Modi et al., 2014; Simpson et al., 2017). Significantly, several studies have reported its ability to not only increase plasma OXT levels, but sustained increases in CSF OXT levels, as well (Modi et al., 2014; Simpson et al., 2017). Some suggestion has been made of using ultrasonic disruption of the BBB by focused pulses. While rodent and non-human primate studies have found no long-term negative consequences, the delivery of OXT or an analog has not been tested and the chance of hemorrhagic transformation in stroke means it could be highly dangerous to use for this specific application (Choi et al., 2011; Downs et al., 2015). Finally, the use of nanoparticles as a carrier method to enhance BBB penetrance of peptides is an exciting addition to therapeutic research that could revolutionize CNS drug delivery including OXT or an OXTR agonist (Zaman et al., 2018; Oppong-Damoah et al., 2019). While further investigation is needed, there is hope this can provide an effective, noninvasive, and safe option for OXTR modulation.

An additional challenge in OXTR targeting is that these receptors share around 40-50\% homology with vasopressin receptors (Gimpl and Fahrenholz, 2001); moreover, these receptors can heterodimerize with each other (Terrillon et al., 2003). OXT and vasopressin differ at only two of their nine residues (Richter, 1983; Ivell and Richter, 1984). Vasopressin is also a partial agonist at OXTRs with only two residues in the binding pocket conferring a higher sensitivity to OXT (Chini et al., 1996). OXT can also act as a partial agonist at vasopressin receptors due to these similar binding sites (Mouillac et al., 1995). An excellent review of this issue and other considerations like bivalent agonists and $\mathrm{G}$ protein-specific ligands provides more detailed insight (Chini and Manning, 2007). More recently, truncated versions of OXT peptides have shown potency as agonists without off-target and dangerous V1a receptor agonism 
(Kablaoui et al., 2018). Surprisingly, the reduced molecular weight did not lead to an increase in permeability for the small cyclic analog (Kablaoui et al., 2018). These analogs then are a potential breakthrough for specific targeting of the OXTR in the periphery but does not solve the problem of $\mathrm{BBB}$ permeability for modulating CNS OXTRs.

The half-life of OXT has been studied extensively, but all show relatively short periods of action. In blood and plasma the half-life of OXT is only $4-5 \mathrm{~min}$ and in pregnant women even lower at 2-3 min (Leng and Sabatier, 2016). The halflife of OXT was reported to be higher in CSF or after an intracerebral injection reported at around $20 \mathrm{~min}$ (Mens et al., 1983). Regardless, the short window of action is likely not desirable for a drug meant to create long term behavioral modifications. One suggestion has been to use non-peptide agonists or antagonists for the receptor. Non-peptide agonists and antagonists can have a longer half-life as endogenous

TABLE 1 | Potential effects of oxytocin receptor activation in cerebrovascular and post-stroke environment.

\begin{tabular}{|c|c|c|}
\hline Domain & Effect & Citation \\
\hline $\begin{array}{l}\text { Cellular } \\
\text { differentiation }\end{array}$ & $\begin{array}{l}\text { Induces cellular proliferation through } \\
\text { phosphorylation of MAPK (ERK5). }\end{array}$ & $\begin{array}{l}\text { Hansenne et al., 2005; } \\
\text { Devost et al., 2008; Stary } \\
\text { et al., } 2019\end{array}$ \\
\hline $\begin{array}{l}\text { Cellular } \\
\text { proliferation }\end{array}$ & $\begin{array}{l}\text { Aids in cellular proliferation through } \\
\text { PKC activation of eEF2 by } \\
\text { dephosphorylation, and Src } \\
\text { dependent mechanisms. }\end{array}$ & $\begin{array}{l}\text { Cassoni, 2006; Devost } \\
\text { et al., 2008; Deing et al., } \\
2013\end{array}$ \\
\hline $\begin{array}{l}\text { Cellular } \\
\text { migration }\end{array}$ & $\begin{array}{l}\text { The PLC pathway activates Akt/PI3K } \\
\text { to influence endothelial cell migration. } \\
\text { Reduces the transendothelial cell } \\
\text { migration of immune cells. }\end{array}$ & $\begin{array}{l}\text { Cattaneo et al., 2009; Viero } \\
\text { et al., 2010; Erkanli et al., } \\
\text { 2013; Liu et al., } 2017\end{array}$ \\
\hline $\begin{array}{l}\text { Synaptic } \\
\text { plasticity }\end{array}$ & $\begin{array}{l}\text { Leads to upregulation of plasticity } \\
\text { related proteins and neurotrophins. }\end{array}$ & $\begin{array}{l}\text { Havranek et al., 2015; } \\
\text { Bakos et al., } 2018\end{array}$ \\
\hline Vasoactivity & $\begin{array}{l}\text { Promotes vasodilation in small } \\
\text { vessels, but might promote } \\
\text { vasoconstriction in large vessels; } \\
\text { dependent on endothelial versus } \\
\text { smooth muscle contributions. }\end{array}$ & $\begin{array}{l}\text { Altura and Altura, 1984; } \\
\text { Uvnäs-Moberg, 1998; } \\
\text { Thibonnier et al., 1999b }\end{array}$ \\
\hline $\begin{array}{l}\text { Glucose } \\
\text { uptake }\end{array}$ & $\begin{array}{l}\text { Encourages the uptake of glucose in } \\
\text { most cell types. }\end{array}$ & $\begin{array}{l}\text { Lee et al., 2008; Florian } \\
\text { et al., } 2010\end{array}$ \\
\hline $\begin{array}{l}\text { Autonomic } \\
\text { nervous } \\
\text { system }\end{array}$ & $\begin{array}{l}\text { Increases parasympathetic tone over } \\
\text { sympathetic tone leading to } \\
\text { decreased reactivity. }\end{array}$ & $\begin{array}{l}\text { Ebner et al., 2005; Huber } \\
\text { et al., } 2005\end{array}$ \\
\hline $\begin{array}{l}\text { Blood } \\
\text { pressure }\end{array}$ & Lowers blood pressure. & $\begin{array}{l}\text { Petersson et al., 1996; } \\
\text { Light et al., } 2005\end{array}$ \\
\hline Heart rate & $\begin{array}{l}\text { Decreases heart rate and cardiac } \\
\text { output through ANP, however, some } \\
\text { pregnant women experience } \\
\text { increases. }\end{array}$ & $\begin{array}{l}\text { Yashpal et al., 1987; } \\
\text { Gutkowska et al., 1997; } \\
\text { Rabow et al., } 2018\end{array}$ \\
\hline $\begin{array}{l}\text { Antioxidant } \\
\text { Protection }\end{array}$ & $\begin{array}{l}\text { Suggested to support an } \\
\text { anti-inflammatory phenotype, but it } \\
\text { remains unclear whether the receptor } \\
\text { or peptide is more responsible. }\end{array}$ & $\begin{array}{l}\text { Szeto et al., 2008; Rashed } \\
\text { et al., 2011; Deing et al., } \\
\text { 2013; Honceriu et al., } \\
\text { 2016; Polshekan et al., } \\
\text { 2016; Wang et al., } 2018\end{array}$ \\
\hline Inflammation & $\begin{array}{l}\text { Pushes most inflammatory cells } \\
\text { toward an anti-inflammatory } \\
\text { phenotype, though a specific } \\
\text { mechanism is unknown. Candidates } \\
\text { include activity at NF-к } \beta \text { and RAGE. }\end{array}$ & $\begin{array}{l}\text { Jankowski et al., 2010; } \\
\text { Metz et al., 2012; Yuan } \\
\text { et al., 2016; Wang et al., } \\
\text { 2018; Garrido-Urbani et al., } \\
\text { 2018; An et al., } 2019\end{array}$ \\
\hline
\end{tabular}

peptidases do not recognize such molecules (Evans et al., 1992). Many of the non-peptide OXT analogs tested to date have shown good to strong efficacy and affinity profiles (Hicks et al., 2012, 2014). However, there are currently no selective non-peptide OXTR agonists in clinical trials, although the WAY 267464 agonist is available for basic research (Ring et al., 2010). Since the recent discovery that methylated WAY 267464 becomes an antagonist at the OXTR instead of its typical agonistic effect, this has opened a possibility to further predictive models for specific nonpeptide agonists and antagonists (Jorgensen et al., 2016; Uba et al., 2020). Synthetic OXT peptides such as pitocin or syntocinon behave very similarly to endogenous OXT, whereas peptide analogs such as carbetocin have shown a longer halflife than OXT and fared better clinically (Manning et al., 2012). Another alternative that can prolong the half-life of the peptide is lipidation. In fact, Cherepanov and coworkers have created several analogs of OXT with palmitoyl groups added to various residues (Cherepanov et al., 2017). These analogs were able to induce behavioral changes out to $24 \mathrm{~h}$ indicating longer halflives, though the ability to induce intracellular calcium uncaging through the OXTR was much less than the endogenous peptide (Cherepanov et al., 2017). With respect to receptor antagonism, OXTR antibodies bound to the surface of liposomes have been tested, but only in targeting myometrium at this point (Hua, 2019; Hua and Vaughan, 2019).

In summary, the complex nature of OXTR biology, with diverse, context-dependent cellular processing, homology with the vasopressin receptors, and ubiquitous expression peripherally and centrally, present challenges to the implementation of promising treatments. Nevertheless, that should not discourage the continuing search for specific and safe options. Certainly, the multitude of potential conditions, including ischemic injury, that might benefit from targeting the OXTR, and the history of successfully targeting GPCRs for treatments in general, should only serve to inspire more promising strategies and results in the future.

\section{CONCLUSION}

Oxytocin was an early forbearer in peptide hormone research. As such, its "receptive substance" as proposed by Langley's receptor theory (Maehle et al., 2002; Maehle, 2009) has inspired scientific interest in the OXTR for decades. Within this review, we have examined the foremost research on the functions of the OXTR at the cellular level and the consequences of this GPCR at the organismal level for both humans and animals, particularly with respect to vascular health and cerebrovascular dysfunction including stroke. These findings are summarized in Table 1. As translational research has come into its own, the structural, mechanistic, and behavioral data arising from OXTR studies support the utility of targeting these receptors in preclinical studies of cerebrovascular insults. In particular, there is therapeutic rationale for targeting the OXTR in the treatment and management of ischemic stroke and, potentially, vascular dementia. Secondly, the significant and ongoing amount of basic research into OXTR function should provide optimism 
that understanding the mechanistic role of this receptor in health and disease will continue to refine therapeutic strategies for these disorders.

\section{AUTHOR CONTRIBUTIONS}

EM researched and served as the principle author of the review. SC served as the editor and secondary author of the

\section{REFERENCES}

Abbott, N. J., Rönnbäck, L., and Hansson, E. (2006). Astrocyte-endothelial interactions at the blood-brain barrier. Nat. Rev. Neurosci. 7, 41-53. doi: 10. $1038 / \mathrm{nrn} 1824$

Adan, R. A. (1995). Rat oxytocin receptor in brain, pituitary, mammary gland, and uterus: partial sequence and immunocytochemical localization. Endocrinology 136, 4022-4028. doi: 10.1210/en.136.9.4022

Ahmed, M. A., and Elosaily, G. M. (2011). Role of oxytocin in deceleration of early atherosclerotic inflammatory processes in adult male rats. Int. J. Clin. Exp. Med. 4, 169-178.

Alizadeh, A. M., Faghihi, M., Khori, V., Sohanaki, H., Pourkhalili, K., Mohammadghasemi, F., et al. (2012). Oxytocin protects cardiomyocytes from apoptosis induced by ischemia-reperfusion in rat heart: role of mitochondrial ATP-dependent potassium channel and permeability transition pore. Peptides 36, 71-77. doi: 10.1016/j.peptides.2012.03.023

Altura, B. M., and Altura, B. T. (1984). Actions of vasopressin, oxytocin, and synthetic analogs on vascular smooth muscle. Fed. Proc. 43, 80-86.

Alvares, G. A., Hickie, I. B., and Guastella, A. J. (2010). Acute effects of intranasal oxytocin on subjective and behavioral responses to social rejection. Exp. Clin. Psychopharmacol. 18, 316-321. doi: 10.1037/a0019719

Ameli, P. A., Ameli, N. J., Gubernick, D. M., Ansari, S., Mohan, S., Satriotomo, I., et al. (2014). Role of vasopressin and its antagonism in stroke related edema. J. Neurosci. Res. 92, 1091-1099. doi: 10.1002/jnr.23407

An, X., Sun, X., Hou, Y., Yang, X., Chen, H., Zhang, P., et al. (2019). Protective effect of oxytocin on LPS-induced acute lung injury in mice. Sci. Rep. 9, 1-11. doi: 10.1038/s41598-019-39349-1

Anagnostou, E., Soorya, L., Brian, J., Dupuis, A., Mankad, D., Smile, S., et al. (2014). Intranasal oxytocin in the treatment of autism spectrum disorders: a review of literature and early safety and efficacy data in youth. Brain Res. 1580, 188-198. doi: 10.1016/j.brainres.2014.01.049

Andari, E., Nishitani, S., Kaundinya, G., Caceres, G. A., Morrier, M. J., Ousley, O., et al. (2020). Epigenetic modification of the oxytocin receptor gene: implications for autism symptom severity and brain functional connectivity. Neuropsychopharmacology 45, 1150-1158. doi: 10.1038/s41386-0200610-6

Antoni, F. A., and Chadio, S. E. (1989). Essential role of magnesium in oxytocinreceptor affinity and ligand specificity. Biochem. J. 257, 611-614. doi: 10.1042/ bj2570611

Aoyagi, T., Birumachi, J. I., Hiroyama, M., Fujiwara, Y., Sanbe, A., Yamauchi, J., et al. (2007). Alteration of glucose homeostasis in V1a vasopressin receptordeficient mice. Endocrinology 148, 2075-2084. doi: 10.1210/en.2006-1315

Argiolas, A., and Gessa, G. L. (1991). Central functions of oxytocin. Neurosci. Biobehav. Rev. 15, 217-231. doi: 10.1016/S0149-7634(05)80002-8

Arias del Razo, R., Berger, T., Conley, A. J., Freeman, S. M., Goetze, L. R., Jacob, S., et al. (2020). Effects of chronic intranasal oxytocin on behavior and cerebral glucose uptake in juvenile titi monkeys. Psychoneuroendocrinology 113:104494. doi: 10.1016/j.psyneuen.2019.104494

Bakos, J., Srancikova, A., Havranek, T., and Bacova, Z. (2018). Molecular mechanisms of oxytocin signaling at the synaptic connection. Neural Plast. 2018:4864107. doi: 10.1155/2018/4864107

Bale, T. L., Davis, A. M., Auger, A. P., Dorsa, D. M., and McCarthy, M. M. (2001). CNS region-specific oxytocin receptor expression: importance in regulation of anxiety and sex behavior. J. Neurosci. 21, 2546-2552. doi: 10.1523/jneurosci.2107-02546.2001 review. Both authors contributed to the article and approved the submitted version.

\section{FUNDING}

This work was supported by NIH grants AG014449, AG060731, and AG053760, as well as the Saint Mary's Foundation and Miles for Memories of Battle Creek, MI, United States.

Bale, T. L., and Dorsa, D. M. (1997). Cloning, novel promoter sequence, and estrogen regulation of a rat oxytocin receptor gene. Endocrinology 138, 11511158. doi: 10.1210/endo.138.3.4998

Balmus, I. M., Strungaru, S., Nicoara, M., Plavan, G., Cojocaru, S. I, and Simion, L. (2017). Preliminary data regarding the effects of oxytocin administration on the oxidative stress status of zebrafish (danio rerio). Rev Chim. 68, 1640-1643. doi: 10.37358/rc.17.7.5734

Bang, M., Kang, I., Kim, S. J., Park, J. Y., Kim, K. R., Lee, S. Y., et al. (2019). Reduced DNA methylation of the oxytocin receptor gene is associated with anhedoniaasociality in women with recent-onset schizophrenia and ultra-high risk for psychosis. Schizophr. Bull. 45, 1279-1290. doi: 10.1093/schbul/sbz016

Barberis, C., Mouillac, B., and Durroux, T. (1998). Structural bases of vasopressin/oxytocin receptor function. J. Endocrinol. 156, 223-229. doi: 10. 1677/joe.0.1560223

Bari, F., Enico, R. A., Louis, T. M., and Busija, D. W. (1997). Influence of hypoxia/ischemia on cerebrovascular responses to oxytocin in piglets. J. Vasc. Res. 34, 312-320. doi: 10.1159/000159239

Barone, F. C., and Parsons, A. A. (2000). Therapeutic potential of antiinflammatory drugs in focal stroke. Expert Opin. Investig. Drugs 9, 2281-2306. doi: 10.1517/13543784.9.10.2281

Bartley, J., Soltau, T., Wimborne, H., Kim, S., Martin-Studdard, A., Hess, D., et al. (2005). BrdU-positive cells in the neonatal mouse hippocampus following hypoxic-ischemic brain injury. BMC Neurosci. 6:15. doi: 10.1186/14712202-6-15

Di Benedetto, A., Sun, L., Zambonin, C. G., Tamma, R., Nico, B., Calvano, C. D., et al. (2014). Osteoblast regulation via ligand-activated nuclear trafficking of the oxytocin receptor. Proc. Natl. Acad. Sci. U.S.A. 111, 16502-16507. doi: 10.1073/pnas.1419349111

Benovic, J. L., Kühn, H., Weyand, I., Codina, J., Caron, M. G., and Lefkowitz, R. J. (1987). Functional desensitization of the isolated beta-adrenergic receptor by the beta-adrenergic receptor kinase: potential role of an analog of the retinal protein arrestin (48-KDa protein). Proc. Natl. Acad. Sci. U.S.A. 84, 8879-8882. doi: $10.1073 /$ pnas.84.24.8879

Bir, S. C., Xiong, Y., Kevil, C. G., and Luo, J. (2012). Emerging role of PKA/eNOS pathway in therapeutic angiogenesis for ischaemic tissue diseases. Cardiovasc. Res. 95, 7-18. doi: 10.1093/cvr/cvs143

Boccia, M. L., Petrusz, P., Suzuki, K., Marson, L., and Pedersen, C. A. (2013). Immunohistochemical localization of oxytocin receptors in human brain. Neuroscience 253, 155-164. doi: 10.1016/j.neuroscience.2013.08.048

Boksa, P., Zhang, Y., and Nouel, D. (2015). Maternal oxytocin administration before birth influences the effects of birth anoxia on the neonatal rat brain. Neurochem. Res. 40, 1631-1643. doi: 10.1007/s11064-015-1645-7

Bourne, A. W., and Burn, J. H. (1928). ). The action of oxytocin and vasopressin on the uterus in labour. Lancet 212, 694-695. doi: 10.1016/S0140-6736(00) 84559-6

Breton, C., Neculcea, J., and Zingg, H. H. (1996). Renal oxytocin receptor messenger ribonucleic acid: characterization and regulation during pregnancy and in response to ovarian steroid treatment. Endocrinology 137, 2711-2717. doi: 10.1210/endo.137.7.8770890

Bruel-Jungerman, E., Veyrac, A., Dufour, F., Horwood, J., Laroche, S., and Davis, S. (2009). Inhibition of PI3K-Akt signaling blocks exercise-mediated enhancement of adult neurogenesis and synaptic plasticity in the dentate gyrus. PLoS One 4:e7901. doi: 10.1371/journal.pone.0007901

Busnelli, M., and Chini, B. (2018). "Molecular basis of oxytocin receptor signalling in the brain: what we know and what we need to know," in Behavioral 
Pharmacology of Neuropeptides: Oxytocin, eds R. Hurlemann, and V. Grinevich (Berlin: Springer International Publishing), 3-29. doi: 10.1007/7854_2017_6

Busnelli, M., Kleinau, G., Muttenthaler, M., Stoev, S., Manning, M., Bibic, L., et al. (2016). Design and characterization of superpotent bivalent ligands targeting oxytocin receptor dimers via a channel-like structure. J. Med. Chem. 59, 71527166. doi: 10.1021/acs.jmedchem.6b00564

Caglayan, A. B., Beker, M. C., Caglayan, B., Yalcin, E., Caglayan, A., Yulug, B., et al. (2019). Acute and post-acute neuromodulation induces stroke recovery by promoting survival signaling, neurogenesis, and pyramidal tract plasticity. Front. Cell. Neurosci. 13:144. doi: 10.3389/fncel.2019.00144

Cassoni, P. (2006). Oxytocin induces proliferation and migration in immortalized human dermal microvascular endothelial cells and human breast tumorderived endothelial cells. Mol. Cancer Res. 4, 351-359. doi: 10.1158/1541-7786. MCR-06-0024

Cattaneo, M. G., Chini, B., and Vicentini, L. M. (2008). Oxytocin stimulates migration and invasion in human endothelial cells. Br. J. Pharmacol. 153, 728-736. doi: 10.1038/sj.bjp.0707609

Cattaneo, M. G., Lucci, G., and Vicentini, L. M. (2009). Oxytocin stimulates in vitro angiogenesis via a Pyk-2/Src-dependent mechanism. Exp. Cell Res. 315, 3210-3219. doi: 10.1016/j.yexcr.2009.06.022

Ceanga, M., Spataru, A., and Zagrean, A. M. (2010). Oxytocin is neuroprotective against oxygen-glucose deprivation and reoxygenation in immature hippocampal cultures. Neurosci. Lett. 477, 15-18. doi: 10.1016/j.neulet.2010.04.024

Chatterjee, O., Patil, K., Sahu, A., Gopalakrishnan, L., Mol, P., Advani, J., et al. (2016). An overview of the oxytocin-oxytocin receptor signaling network. J. Cell Commun. Signal. 10, 355-360. doi: 10.1007/s12079-016-0353-7

Chen, Y. A., Tsai, Y. C., Chen, Y. D., Liu, D. Z., Young, T. H., and Tsai, L. K. (2020). Intraventricular medium B treatment benefits an ischemic stroke rodent model via enhancement of neurogenesis and anti-apoptosis. Sci. Rep. 10:6596. doi: 10.1038/s41598-020-63598-0

Cherepanov, S. M., Yokoyama, S., Mizuno, A., Ichinose, W., Lopatina, O., Shabalova, A. A., et al. (2017). Structure-specific effects of lipidated oxytocin analogs on intracellular calcium levels, parental behavior, and oxytocin concentrations in the plasma and cerebrospinal fluid in mice. Pharmacol. Res. Perspect. 5, 1-14. doi: 10.1002/prp2.290

Chini, B., and Manning, M. (2007). Agonist selectivity in the oxytocin/vasopressin receptor family: new insights and challenges. Biochem. Soc. Trans. 35, 737-741. doi: 10.1042/BST0350737

Chini, B., Mouillac, B., Ala, Y., Balestre, M. N., Cotte, N., TrumppKallmeyer, S., et al. (1995). ). Molecular basis for agonist selectivity in the vasopressin/oxytocin receptor family. Adv. Exp. Med. Biol. 395, 321-328.

Chini, B., Verhage, M., and Grinevich, V. (2017). The action radius of oxytocin release in the mammalian CNS: from single vesicles to behavior. Trends Pharmacol. Sci. 38, 982-991. doi: 10.1016/j.tips.2017.08.005

Chini, B., Mouillac, B., Balestreb, M., Trumpp-Kallmeyer, S., Hoflack, J., Hibert, M., et al. (1996). Two aromatic residues regulate the response of the human oxytocin receptor to the partial agonist arginine vasopressin. FEBS Lett. 397, 201-206. doi: 10.1016/s0014-5793(96)01135-0

Chitnis, T., and Weiner, H. L. (2017). CNS inflammation and neurodegeneration. J. Clin. Invest. 127, 3577-3587. doi: 10.1172/JCI90609

Choi, D. H., Kim, J. H., Lee, K. H., Kim, H. Y., Kim, Y. S., Choi, W. S., et al. (2015). ). Role of neuronal NADPH oxidase 1 in the peri-infarct regions after stroke. PLoS One 10:e0116814. doi: 10.1371/journal.pone.0116814

Choi, J. J., Selert, K., Vlachos, F., Wong, A., and Konofagou, E. E. (2011). Noninvasive and localized neuronal delivery using short ultrasonic pulses and microbubbles. Proc. Natl. Acad. Sci. U.S.A. 108, 16539-16544. doi: 10.1073/ pnas. 1105116108

Clarkson, A. N., Huang, B. S., MacIsaac, S. E., Mody, I., and Carmichael, S. T. (2010). Reducing excessive GABA-mediated tonic inhibition promotes functional recovery after stroke. Nature 468, 305-309. doi: 10.1038/ nature09511

Conti, F., Sertic, S., Reversi, A., and Chini, B. (2009). Intracellular trafficking of the human oxytocin receptor: evidence of receptor recycling via a Rab4/Rab5 "short cycle. Am. J. Physiol. Endocrinol. Metab. 296, E532-E542. doi: 10.1152/ ajpendo.90590.2008

Costa-E-Sousa, R. H., Pereira-Junior, P. P., Oliveira, P. F., Olivares, E. L., WerneckDe-Castro, J. P. S., Mello, D. B., et al. (2005). Cardiac effects of oxytocin: is there a role for this peptide in cardiovascular homeostasis? Regu. Pept. 132, 107-112. doi: 10.1016/j.regpep.2005.09.011

Cottet, M., Albizu, L., Perkovska, S., Jean-Alphonse, F., Rahmeh, R., Orcel, H., et al. (2010). Past, present and future of vasopressin and oxytocin receptor oligomers, prototypical GPCR models to study dimerization processes. Curr. Opin. Pharmacol. 10, 59-66. doi: 10.1016/j.coph.2009.10.003

Daneman, R., and Prat, A. (2015). The blood-brain barrier. Cold Spring Harb. Perspect. Biol. 7, a020412. doi: 10.1101/cshperspect.a020412

Davis, S., and Vanhoutte, P. (2000). MAPK/ERK cascade targets both Elk-1 and CAMP response element-binding protein to control long-term potentiationdependent gene expression in the dentate gyrus. J. Neurosci. 20, 4563-4572. doi: 10.1523/jneurosci.20-12-04563.2000

Deing, V., Roggenkamp, D., Kühnl, J., Gruschka, A., Stäb, F., Wenck, H., et al. (2013). Oxytocin modulates proliferation and stress responses of human skin cells: implications for atopic dermatitis. Exp. Dermatol. 22, 399-405. doi: 10. 1111/exd.12155

DeMayo, M. M., Song, Y. J. C., Hickie, I. B., and Guastella, A. J. (2017). A review of the safety, efficacy and mechanisms of delivery of nasal oxytocin in children: therapeutic potential for autism and prader-willi syndrome, and recommendations for future research. Pediatr. Drugs 19, 391-410. doi: 10.1007/ s40272-017-0248-y

Dempsey, R. J., and Kalluri, H. S. G. (2007). Ischemia-induced neurogenesis: role of growth factors. Neurosurg. Clin. N. Am. 18, 183-190. doi: 10.1016/j.nec.2006. 10.011

Devost, D., Wrzal, P., and Zingg, H. H. (2008). Oxytocin receptor signalling. Prog. Brain Res. 170, 167-176. doi: 10.1016/S0079-6123(08)00415-9

Dong, C., Filipeanu, C. M., Duvernay, M. T., and Wu, G. (2007). Regulation of g protein-coupled receptor export trafficking. Biochim. Biophys. Acta Biomembr. 1768, 853-870. doi: 10.1016/j.bbamem.2006.09.008

Downs, M. E., Buch, A., Sierra, C., Karakatsani, M. E., Chen, S., Konofagou, E. E., et al. (2015). Long-term safety of repeated blood-brain barrier opening via focused ultrasound with microbubbles in non-human primates performing a cognitive task. PLoS One 10:e0125911. doi: 10.1371/journal.pone.0125911

Düşünceli, F., Işeri, S. Ö, Ercan, F., Gedik, N., Yegen, C., and Yegen, B. Ç (2008). Oxytocin alleviates hepatic ischemia-reperfusion injury in rats. Peptides 29, 1216-1222. doi: 10.1016/j.peptides.2008.02.010

Ebner, K., Bosch, O. J., Krömer, S. A., Singewald, N., and Neumann, I. D. (2005). Release of oxytocin in the rat central amygdala modulates stress-coping behavior and the release of excitatory amino acids. Neuropsychopharmacology 30, 223-230. doi: 10.1038/sj.npp.1300607

Erbas, O., Taşkı ran, D., Oltulu, F., Yavaşoð̋lu, A., Bora, S., Bilge, O., et al. (2017). Oxytocin provides protection against diabetic polyneuropathy in rats. Neurol. Res. 39, 45-53. doi: 10.1080/01616412.2016.1249630

Erkanli, K., Erkanli Senturk, G., Aydin, U., Arbak, S., Ercan, F., Tuncdemir, M., et al. (2013). Oxytocin protects rat skeletal muscle against ischemia/reperfusion injury. Ann. Vasc. Surg. 27, 662-670. doi: 10.1016/j.avsg.2012.10.012

Erkanli Senturk, G., Erkanli, K., Aydin, U., Yucel, D., Isiksacan, N., Ercan, F., et al. (2013). The protective effect of oxytocin on ischemia/reperfusion injury in rat urinary bladder. Peptides 40, 82-88. doi: 10.1016/j.peptides.2012.12.006

Moghadam, S. E., Tameh, A. A., Vahidinia, Z., Atlasi, M. A., Bafrani, H. H., and Naderian, H. (2018). Neuroprotective effects of oxytocin hormone after an experimental stroke model and the possible role of calpain-1. J. Stroke Cerebrovasc. Dis. 27, 724-732. doi: 10.1016/j.jstrokecerebrovasdis.2017. 10.020

Evans, B. E., Leighton, J. L., Rittle, K. E., Gilbert, K. F., Lundell, G. F., Gould, N. P., et al. ( (1992). Orally active, nonpeptide oxytocin antagonists. J. Med. Chem. 35, 3919-3927. doi: 10.1021/jm00099a020

Faghihi, M., Alizadeh, A. M., Khori, V., Latifpour, M., and Khodayari, S. (2012). The role of nitric oxide, reactive oxygen species, and protein kinase $\mathrm{C}$ in oxytocin-induced cardioprotection in ischemic rat heart. Peptides 37, 314-319. doi: 10.1016/j.peptides.2012.08.001

Fanelli, F., Barbier, P., Zanchetta, D., de Benedetti, P. G., and Chini, B. (1999). Activation mechanism of human oxytocin receptor: a combined study of experimental and computer-simulated mutagenesis. Mol. Pharmacol. 56, 214225. doi: 10.1124/MOL.56.1.214

Faraci, F. M. (1989). Effects of endothelin and vasopressin on cerebral blood vessels. Am. J. Physiol. 257, 799-803. doi: 10.1152/ajpheart.1989.257. 3.h799 
Florian, M., Jankowski, M., and Gutkowska, J. (2010). Oxytocin increases glucose uptake in neonatal rat cardiomyocytes. Endocrinology 151, 482-491. doi: 10. 1210/en.2009-0624

Freidinger, R. M., and Pettibone, D. J. (1997). Small molecule ligands for oxytocin and vasopressin receptors. Med. Res. Rev. 17, 1-16. doi: 10.1002/(sici)10981128(199701) 17:1<1::aid-med1>3.0.co;2-5

Fuchs, A., Fuchs, F., Husslein, P., and Soloff, M. S. (1984). Oxytocin receptors in the human uterus during pregnancy and parturition. Am. J. Obstet. Gynecol. 150, 734-741. doi: 10.1016/0002-9378(84)90677-X

Galbusera, A., De Felice, A., Girardi, S., Bassetto, G., Maschietto, M., Nishimori, K., et al. (2017). Intranasal oxytocin and vasopressin modulate divergent brainwide functional substrates. Neuropsychopharmacology 42, 1420-1434. doi: 10.1038/ npp. 2016.283

Garrido-Urbani, S., Deblon, N., Poher, A. L., Caillon, A., Ropraz, P., RohnerJeanrenaud, F., et al. (2018). Inhibitory role of oxytocin on TNF $\alpha$ expression assessed in vitro and in vivo. Diabetes Metab. 44, 292-295. doi: 10.1016/j.diabet. 2017.10.004

Garrott, K., Dyavanapalli, J., Cauley, E., Dwyer, M. K., Kuzmiak-Glancy, S., Wang, X., et al. (2017). Chronic activation of hypothalamic oxytocin neurons improves cardiac function during left ventricular hypertrophy-induced heart failure. Cardiovasc. Res. 113, 1318-1328. doi: 10.1093/cvr/cvx084

Ghorbanzadeh, V., Jafarpour, A., Pirnia, A., Pajouhi, N., Khaksarian, M., Veiskarami, S., et al. (2020). The role of vasopressin V1A and oxytocin OTR receptors in protective effects of arginine vasopressin against $\mathrm{H} 2 \mathrm{O} 2$-induced oxidative stress in H9C2 cells. Arch. Physiol. Biochem. 6, 1-6. doi: 10.1080/ 13813455.2020.1729816

Gimpl, G., and Fahrenholz, F. (2000). Human oxytocin receptors in cholesterolrich vs. cholesterol-poor microdomains of the plasma membrane. Eur. J. Biochem. 267, 2483-2497. doi: 10.1046/j.1432-1327.2000.01280.x

Gimpl, G., and Fahrenholz, F. (2001). The oxytocin receptor system: structure, function, and regulation. Physiol. Rev. 81, 629-683. doi: 10.1152/physrev.2001. 81.2.629

Gimpl, G., Wiegand, V., Burger, K., and Fahrenholz, F. (2002). Cholesterol and steroid hormones: modulators of oxytocin receptor function. Prog. Brain Res. 139, 43-55. doi: 10.1016/S0079-6123(02)39006-X

Gonzalez-Reyes, A., Menaouar, A., Yip, D., Danalache, B., Plante, E., Noiseux, N., et al. (2015). Molecular mechanisms underlying oxytocin-induced cardiomyocyte protection from simulated ischemia-reperfusion. Mol. Cell. Endocrinol. 412, 170-181. doi: 10.1016/j.mce.2015.04.028

Goodin, B. R., Anderson, A. J. B., Freeman, E. L., Bulls, H. W., Robbins, M. T., and Ness, T. J. (2014). Intranasal oxytocin administration is associated with enhanced endogenous pain inhibition and reduced negative mood states. Clin. J. Pain 93, 4. doi: 10.1097/AJP.0000000000000166

Grazzini, E., Guillon, G., Mouillac, B., and Zingg, H. H. (1998). Inhibition of oxytocin receptor function by firect binding of progesterone. Nature 392, 509-512. doi: 10.1038/33176

Gregory, S. G., Connelly, J. J., Towers, A. J., Johnson, J., Biscocho, D., Markunas, C. A., et al. (2009). Genomic and epigenetic evidence for oxytocin receptor deficiency in autism. BMC Med. 7:62. doi: 10.1186/1741-7015-7-62

Grewen, K. M., and Light, K. C. (2011). Plasma oxytocin is related to lower cardiovascular and sympathetic reactivity to stress. Biol. Psychol. 87, 340-349. doi: 10.1016/j.biopsycho.2011.04.003

Griling, E. M. K., and Eddy, C. A. (1928). The hyperglycemic effect of vasopressin, oxytocin and pituitrin. Exp. Biol. Med. 26, 146-147. doi: 10.3181/00379727-264186

Grinevich, V. H., Knobloch-Bollmann, S., Eliava, M., Busnelli, M., and Chini, B. (2016). Assembling the puzzle: pathways of oxytocin signaling in the brain. Biol. Psychiatry 79, 155-164. doi: 10.1016/j.biopsych.2015.04.013

Grinevich, V. H., and Neumann, I. D. (2020). Brain oxytocin: how puzzle stones from animal studies translate into psychiatry. Mol. Psychiatry 1-15. doi: 10. 1038/s41380-020-0802-9

Grotegut, C. A., Mao, L., Pierce, S. L., Swamy, G. K., Heine, R. P., and Murtha, A. P. (2016). Enhanced uterine contractility and stillbirth in mice lacking $g$ protein-coupled receptor kinase 6 (GRK6): implications for oxytocin receptor desensitization. Mol. Endocrinol. 30, 455-468. doi: 10.1210/me.2015-1147

Grotegut, C. A., Ngan, E., Garrett, M. E., Miranda, M. L., Ashley-Koch, A. E., and Swamy, G. K. (2017). The association of single-nucleotide polymorphisms in the oxytocin receptor and g protein-coupled receptor kinase 6 (GRK6) genes with oxytocin dosing requirements and labor outcomes. Am. J. Obstet. Gynecol. 217, .e1-.e367. doi: 10.1016/j.ajog.2017.05.023

Gruber, C. M. (1928). Blood pressure in unanesthetized animals affected by 'vasopressin,' 'oxytocin', pituitary extract and other drugs. Proc. Soc. Exp. Biol. Med. 26, 243-244. doi: 10.3181/00379727-26-4239

Gutkowska, J., and Jankowski, M. (2012). Oxytocin revisited: its role in cardiovascular regulation. J. Neuroendocrinol. 24, 599-608. doi: 10.1111/j.13652826.2011.02235.x

Gutkowska, J., Jankowski, M., Mukaddam-Daher, S., and McCann, S. M. (2000). Oxytocin is a cardiovascular hormone. Braz. J. Med. Biol. Res. 33, 625-633. doi: 10.1590/S0100-879X2000000600003

Gutkowska, J., Jankowski, M., Lambert, C., Mukaddam-Daher, S., Zingg, H. H., and Mccann, S. M. (1997). Oxytocin releases atrial natriuretic peptide by combining with oxytocin receptors in the heart. Physiology. 94, 11704-11709. doi: 10.1073 /pnas.94.21.11704

Guzzi, F., Zanchetta, D., Cassoni, P., Guzzi, V., Francolini, M., Parenti, M., et al. (2002). Localization of the human oxytocin receptor in caveolin-1 enriched domains turns the receptor-mediated inhibition of cell growth into a proliferative response. Oncogene 21, 1658-1667. doi: 10.1038/sj.onc.1205219

Hansenne, I., Rasier, G., Péqueux, C., Brilot, F., Renard, C. H, Breton, C., et al. (2005). Ontogenesis and functional aspects of oxytocin and vasopressin gene expression in the thymus network. J. Neuroimmunol. 158, 67-75. doi: 10.1016/ j.jneuroim.2004.08.007

Havranek, T., Zatkova, M., Lestanova, Z., Bacova, Z., Mravec, B., Hodosy, J., et al. (2015). Intracerebroventricular oxytocin administration in rats enhances object recognition and increases expression of neurotrophins, microtubule-associated protein 2, and synapsin I. J. Neurosci. Res. 93, 893-901. doi: 10.1002/jnr. 23559

Hicks, C., Jorgensen, W., Brown, C., Fardell, J., Koehbach, J., Gruber, C. W., et al. (2012). The nonpeptide oxytocin receptor agonist WAY 267,464: receptorbinding profile, prosocial effects and distribution of c-Fos expression in adolescent rats. J. Neuroendocrinol. 24, 1012-1029. doi: 10.1111/j.1365-2826. 2012.02311.x

Hicks, C., Ramos, L., Reekie, T., Misagh, G. H., Narlawar, R., Kassiou, M., et al. (2014). Body temperature and cardiac changes induced by peripherally administered oxytocin, vasopressin and the non-peptide oxytocin receptor agonist WAY 267,464: a biotelemetry study in rats. Br. J. Pharmacol. 171, 2868-2887. doi: 10.1111/bph.12613

Hirasawa, M., Kombian, S. B., and Pittman, Q. J. (2001). Oxytocin retrogradely inhibits evoked, but not miniature, EPSCs in the rat supraoptic nucleus: role of N- and P/Q-type calcium channels. J. Physiol. 532, 595-607. doi: 10.1111/j. 1469-7793.2001.0595e.x

Hoare, S., Copland, J. A., Strakova, Z., Ives, K., Jeng, Y. J., Hellmich, M. R., et al. (1999). The proximal portion of the $\mathrm{COOH}$ terminus of the oxytocin receptor is required for coupling to $G(q)$, but not $G(i)$. Independent mechanisms for elevating intracellular calcium concentrations from intracellular stores. J. Biol. Chem. 274, 28682-28689. doi: 10.1074/jbc.274.40.28682

Hollander, E., Novotny, S., Hanratty, M., Yaffe, R., DeCaria, C. M., Aronowitz, B. R., et al. (2003). Oxytocin infusion reduces repetitive behaviors in adults with autistic and asperger's disorders. Neuropsychopharmacology 28, 193-198. doi: 10.1038/sj.npp.1300021

Holtorf, A. P., Furuya, K., Ivell, R., and McArdle, C. A. (1989). Oxytocin production and oxytocin messenger ribonucleic acid levels in bovine granulosa cells are regulated by insulin and insulin-like growth factor-I: dependence on developmental status of the ovarian follicle. Endocrinology 125, 2612-2620. doi: 10.1210/endo-125-5-2612

Honceriu, C., Ciobica, A., Stoica, B., Chirazi, M., and Padurariu, M. (2016). Oxytocin antioxidant effects on wistar rats. Rev Chim. 67, 2246-2249.

Hrabovszky, E., and Liposits, Z. (2008). Novel aspects of glutamatergic signalling in the neuroendocrine system. J. Neuroendocrinol. 20, 743-751. doi: 10.1111/j. 1365-2826.2008.01719.x

Hua, S. (2019). Synthesis and in vitro characterization of oxytocin receptor targeted PEGylated immunoliposomes for drug delivery to the uterus. J. Liposome Res. 29, 357-367. doi: 10.1080/08982104.2018.1556293

Hua, S., and Vaughan, B. (2019). In vitro comparison of liposomal drug delivery systems targeting the oxytocin receptor: a potential novel treatment for obstetric complications. Int. J. Nanomed. 14, 2191-2206. doi: 10.2147/IJN. S198116 
Huber, D., Veinante, P., and Stoop, R. (2005). Vasopressin and oxytocin excite distinct neuronal populations in the central amygdala. Science 308, 245-248. doi: 10.1126/science.1105636

Inoue, T., Yamakage, H., Tanaka, M., Kusakabe, T., Shimatsu, A., and SatohAsahara, N. (2019). Oxytocin suppresses inflammatory responses induced by lipopolysaccharide through inhibition of the EIF- $2 \alpha-\mathrm{ATF} 4$ pathway in mouse microglia. Cells 8:527. doi: 10.3390/cells8060527

Inoue, T., Kimuras, T., Azuma, C., Inazawas, J., Takemura, M., Kikuchi, T., et al. (1994). Structural organization of the human oxytocin receptor gene. J. Biol. Chem. 269, 32451-32456.

Insel, T. R. (1990). Regional changes in brain oxytocin receptors post-partum: timecourse and relationship to maternal behaviour. J. Neuroendocrinol. 2, 539-545. doi: 10.1111/j.1365-2826.1990.tb00445.x

Ivell, R., and Richter, D. (1984). Structure and comparison of the oxytocin and vasopressin genes from rat. Proc. Natl. Acad. Sci. 81, 2006-2010. doi: 10.1073/ pnas.81.7.2006

Jameson, H., Bateman, R., Byrne, P., Dyavanapalli, J., Wang, X., Jain, V., et al. (2016). Oxytocin neuron activation prevents hypertension that occurs with chronic intermittent hypoxia/hypercapnia in rats. Am. J. Physiol. 310, H1549H1557. doi: 10.1152/ajpheart.00808.2015

Jan, W. C., Kao, M. C., Yang, C. H., Chang, Y. Y., and Huang, C. J. (2017). Phosphoinositide 3-Kinase is involved in mediating the anti-inflammation effects of vasopressin. Inflammation 40, 435-441. doi: 10.1007/s10753-0160489-x

Jankowski, M., Bissonauth, V., Gao, L., Gangal, M., Wang, D., Danalache, B., et al. (2010). Anti-Inflammatory effect of oxytocin in rat myocardial infarction. Basic Res. Cardiol. 105, 205-218. doi: 10.1007/s00395-009-0076-5

Jia, J., Cui, Y., Tan, Z., Ma, W., and Jiang, Y. (2020). MicroRNA-579-3p exerts neuroprotective effects against ischemic stroke via anti-inflammation and anti-apoptosis. Neuropsychiatr. Dis. Treat. 16, 1229-1238. doi: 10.2147/NDT. S240698

Jorgensen, W. T., Gulliver, D. W., Werry, E. L., Reekie, T., Connor, M., and Kassiou, M. (2016). Flexible analogues of WAY-267,464: synthesis and pharmacology at the human oxytocin and vasopressin 1a receptors. Eur. J. Med. Chem. 108, 730-740. doi: 10.1016/j.ejmech.2015.11.050

Jurek, B., and Neumann, I. D. (2018). The oxytocin receptor: from intracellular signaling to behavior. Physiol. Rev. 98, 1805-1908. doi: 10.1152/physrev.00031. 2017

Kablaoui, N., Vanase-Frawley, M., and Sciabola, S. (2018). Hybrid peptide-small molecule oxytocin analogs are potent and selective agonists of the oxytocin receptor. Bioorg. Med. Chem. Lett. 28, 415-419. doi: 10.1016/j.bmcl.2017.12.027

Kahles, T., and Brandes, R. P. (2012). NADPH oxidases as therapeutic targets in ischemic stroke. Cell. Mol. Life Sci. 69, 2345-2363. doi: 10.1007/s00018-0121011-8

Kamm, O., Aldrich, T. B., Grotb, I. W., Rowe, L. W., and Bugbee, E. P. (1928). The active principles of the posterior lobe of the pituitary gland. I. The demonstration of the presence of two active principles. II. The separation of the two principles and their concentration in the form of potent solid preparations. J. Am. Chem. Soc. 50, 573-601. doi: 10.1021/ja01389a050

Kaneko, Y., Pappas, C., Tajiri, N., and Borlongan, C. V. (2016). ). Oxytocin modulates GABAAR subunits to confer neuroprotection in stroke in vitro. Sci. Rep. 6, 1-10. doi: 10.1038/srep35659

Karelina, K., Stuller, K. A., Jarrett, B., Zhang, N., Norman, G. J., and Devries, A. C. (2012). Oxytocin mediates social neuroprotection after cerebral ischemia. Stroke 42, 3606-3611. doi: 10.1161/strokeaha.111.628008

van Kesteren, R. E., Tensen, C. P., Smit, A. B., van Minnen, J., Kolakowski, L. F., Meyerhof, W., et al. (1996). Co-evolution of ligand-receptor pairs in the vasopressin/oxytocin superfamily of bioactive peptides. J. Biol. Chem. 271, 3619-3626. doi: 10.1074/jbc.271.7.3619

Kim, Y. K., Yang, E. J., Cho, K., Lim, J. Y., and Paik, N. J. (2014). Functional recovery after ischemic stroke is associated with reduced gabaergic inhibition in the cerebral cortex: a GABA PET study. Neurorehabil. Neural Repair 28, 576-583. doi: 10.1177/1545968313520411

Kimura, T., Makino, Y., Bathgate, R., Ivell, R., Nobunaga, T., Kubota, Y., et al. (1997). The Role of N-Terminal Glycosylation in the Human Oxytocin Receptor. Mol. Hum. Reprod. 3, 957-963. doi: 10.1093/molehr/3.11.957

Kimura, T., Tanizawa, O., Mori, K., Brownstein, M. J., and Okayama, H. (1992). Structure and expression of a human oxytocin receptor. Nature 356, 526-529. doi: $10.1038 / 356526 \mathrm{a} 0$
Kisoh, K., Hayashi, H., Itoh, T., Asada, M., Arai, M., Yuan, B., et al. (2017). Involvement of GSK-3 $\beta$ phosphorylation through PI3-K/Akt in cerebral ischemia-induced neurogenesis in rats. Mol. Neurobiol. 54, 7917-7927. doi: 10.1007/s12035-016-0290-8

Knobloch, H. S., Charlet, A., Hoffmann, L. C., Eliava, M., Khrulev, S., Cetin, A. H., et al. (2012). Evoked axonal oxytocin release in the central amygdala attenuates fear response. Neuron 73, 553-566. doi: 10.1016/j.neuron.2011.11.030

Knox, S. S., and Uvnäs-Moberg, K. (1998). Social isolation and cardiovascular disease: an atherosclerotic pathway? Psychoneuroendocrinology 23, 877-890. doi: 10.1016/S0306-4530(98)00061-4

Kobayashi, H., Yasuda, S., Bao, N., Iwasa, M., Kawamura, I., Yamada, Y., et al. (2009). Postinfarct treatment with oxytocin improves cardiac function and remodeling via activating cell-survival signals and angiogenesis. J. Cardiovasc. Pharmacol. 54, 510-519. doi: 10.1097/FJC.0b013e3181bfac02

Komiyama, N. H., Watabe, A. M., Carlisle, H. J., Porter, K., Charlesworth, P., Monti, J., et al. (2002). SynGAP regulates ERK/MAPK signaling, synaptic plasticity, and learning in the complex with postsynaptic density 95 and NMDA receptor. J. Neurosci. 22, 9721-9732. doi: 10.1523/jneurosci.22-22-09721. 2002

Kuo, J., Hariri, O. R., and Micevych, P. (2009). An interaction of oxytocin receptors with metabotropic glutamate receptors in hypothalamic astrocytes. J. Neuroendocrinol. 21, 1001-1006. doi: 10.1111/j.1365-2826.2009.01922.x

Lee, E. S., Uhm, K. O., Lee, Y. M., Kwon, J., Park, S. H., and Soo, K. H. (2008). Oxytocin stimulates glucose uptake in skeletal muscle cells through the calcium-CaMKK-AMPK pathway. Regul. Pept. 151, 71-74. doi: 10.1016/j. regpep.2008.05.001

Lee, S. Y., Park, S. H., Chung, C., Kim, J. J., Choi, S. Y., and Han, J. S. (2015). Oxytocin protects hippocampal memory and plasticity from uncontrollable stress. Sci. Rep. 5, 1-9. doi: 10.1038/srep18540

Leng, G., and Sabatier, N. (2016). Measuring oxytocin and vasopressin: bioassays, immunoassays and random numbers. J. Neuroendocrinol. 28:10.1111/jne.12413 . doi: $10.1111 /$ jne. 12413

Leng, G., and Ludwig, M. (2016). Intranasal oxytocin: myths and delusions. Biol. Psychiatry 79, 243-250. doi: 10.1016/j.biopsych.2015.05.003

Leuner, B., Caponiti, J. M., and Gould, E. (2012). Oxytocin stimulates adult neurogenesis even under conditions of stress and elevated glucocorticoids. Hippocampus 22, 861-868. doi: 10.1002/hipo.20947

Lévy, F., Batailler, M., Meurisse, M., Keller, M., Cornilleau, F., Moussu, C., et al. (2019). Differential effects of oxytocin on olfactory, hippocampal and hypothalamic neurogenesis in adult sheep. Neurosci. Lett. 713:134520. doi: 10. 1016/j.neulet.2019.134520

Li, T., Wang, P., Wang, S. C., and Wang, Y. F. (2017). Approaches mediating oxytocin regulation of the immune system. Front. Immunol. 7:693. doi: 10.3389/ fimmu.2016.00693

Li, X., Su, L., Zhang, X., Zhang, C., Wang, L., Li, Y., et al. (2017). Ulinastatin downregulates TLR4 and NF-KB expression and protects mouse brains against ischemia/reperfusion injury. Neurol. Res. 39, 367-373. doi: 10.1080/01616412. 2017.1286541

Light, K. C., Grewen, K. M., and Amico, J. A. (2005). More frequent partner hugs and higher oxytocin levels are linked to lower blood pressure and heart rate in premenopausal women. Biol. Psychol. 69, 5-21. doi: 10.1016/j.biopsycho.2004. 11.002

Lin, Y. T., Chen, C. C., Huang, C. C., Nishimori, K., and Hsu, K. S. (2017). Oxytocin stimulates hippocampal neurogenesis via oxytocin receptor expressed in CA3 pyramidal neurons. Nat. Commun 8:537. doi: 10.1038/s41467-017-00675-5

Liu, J., Wang, Y., Akamatsu, Y., Cheng Lee, C., Stetler, R. A., Lawton, M. T., et al. (2013). Vascular remodeling after ischemic stroke: mechanisms and therapeutic potentials. Prog. Neurobiol. 115, 138-156. doi: 10.1016/j.pneurobio.2013. 11.004

Liu, S., Pan, S., Tan, J., Zhao, W., and Liu, F. (2017). Oxytocin inhibits ox-LDLinduced adhesion of monocytic THP-1 cells to human brain microvascular endothelial cells. Toxicol. Appl. Pharmacol. 337, 104-110. doi: 10.1016/j.taap. 2017.10.022

Long, C., and Hillis, A. E. (2016). "Oxytocin as a treatment option in right hemisphere stroke," in Psychology of Empathy: New Research, ed. C. Edwards (New York, NY: Nova Science Publishers, Inc.), 151-171.

Loziæ, M., Šarenac, O., Murphy, D., and Japundžiæ-Žigon, N. (2018). Vasopressin, central autonomic control and blood pressure regulation. Curr. Hypertens. Rep. 20, 1-7. doi: 10.1007/s11906-018-0811-0 
Luttrell, L. M., Ferguson, S. S., Daaka, Y., Miller, W. E., Maudsley, S., Della Rocca, G. J., et al. (1999). B-arrestin-dependent formation of B2 adrenergic receptorSrc protein kinase complexes. Science 283, 655-661. doi: 10.1126/science.283. 5402.655

Luttrell, L. M., Roudabush, F. L., Choy, E. W., Miller, W. E., Field, M. E., Pierce, K. L., et al. (2001). Activation and targeting of extracellular signal-regulated kinases by beta-arrestin scaffolds. Proc. Natl. Acad. Sci. U.S.A. 98, 2449-2454. doi: 10.1073/pnas.041604898

MacDonald, E., Dadds, M. R., Brennan, J. L., Williams, K., Levy, F., and Cauchi, A. J. (2011). A view of safety, side-effects and subjective reactions to intranasal oxytocin in human research. Psychoneuroendocrinology 36, 1114-1126. doi: 10.1016/j.psyneuen.2011.02.015

Maehle, A. H. (2009). A binding question: the evolution of the receptor concept. Endeavour 33, 135-140. doi: 10.1016/j.endeavour.2009.09.001

Maehle, A. H., Prüll, C. R., and Halliwell, R. F. (2002). The emergence of the drug receptor theory. Nat. Rev. Drug Discov. 1, 637-641. doi: 10.1038/nrd875

Maiolino, M., O’Neill, N., Lariccia, V., Amoroso, S., Sylantyev, S., Angelova, P. R., et al. (2019). Inorganic polyphosphate regulates AMPA and NMDA receptors and protects against glutamate excitotoxicity via activation of P2Y receptors. J. Neurosci. 39, 6038-6048. doi: 10.1523/JNEUROSCI.0314-19.2019

Mairesse, J., Zinni, M., Pansiot, J., Hassan-Abdi, R., Demene, C., Colella, M., et al. (2019). Oxytocin receptor agonist reduces perinatal brain damage by targeting microglia. Glia 67, 345-359. doi: 10.1002/glia.23546

Manning, M., Misicka, A., Olma, A., Bankowski, K., Stoev, S., Chini, B., et al. (2012). Oxytocin and vasopressin agonists and antagonists as research tools and potential therapeutics. J. Neuroendocrinol. 24, 609-628. doi: 10.1111/j.13652826.2012.02303.x

Martins, D. A., Mazibuko, N., Zelaya, F., Vasilakopoulou, S., Loveridge, J., Oates, A., et al. (2020). Effects of route of administration on oxytocin-induced changes in regional cerebral blood flow in humans. Nat. Commun. 11, 1-16. doi: 10. 1038/s41467-020-14845-5

Matsuura, K., Nagai, T., Nishigaki, N., Oyama, T., Nishi, J., Wada, H., et al. (2004). Adult cardiac Sca-1-positive cells differentiate into beating cardiomyocytes. J. Biol. Chem. 279, 11384-11391. doi: 10.1074/jbc.M310822200

McKay, E. C., Beck, J. S., Khoo, S. K., Dykema, K. J., Cottingham, S. L., Winn, M. E., et al. (2019). Peri-infarct upregulation of the oxytocin receptor in vascular dementia. J. Neuropathol. Exp. Neurol. 78, 436-452. doi: 10.1093/jnen/nlz023

Mens, W. B., Witter, A., and van Wimersma Greidanus, T. B. (1983). Penetration of neurohypophysial hormones from plasma into cerebrospinal fluid (CSF), half-times of disappearances of these neuropeptides from CSF. Brain Res. 262, 143-149. doi: 10.1016/0006-8993(83)90478-X

Metz, V. V., Kojro, E., Rat, D., and Postina, R. (2012). Induction of RAGE shedding by activation of g protein-coupled receptors. PLoS One 7:e41823. doi: 10.1371/ journal.pone.0041823

Meyer-Lindenberg, A., Domes, G., Kirsch, P., and Heinrichs, M. (2011). Oxytocin and vasopressin in the human brain: social neuropeptides for translational medicine. Nat. Rev. Neurosci. 12, 524-538. doi: 10.1038/nrn3044

Mittaud, P., Labourdette, G., Zingg, H., and Guenot-Di Scala, D. (2002). Neurons modulate oxytocin receptor expression in rat cultured astrocytes: involvement of TGF- $\beta$ and membrane components. Glia 37, 169-177. doi: 10.1002/glia. 10029

Mizumoto, Y., Kimura, T., and Ivell, R. (1997). A genomic element within the third intron of the human oxytocin receptor gene may be involved in transcriptional suppression. Mol. Cell. Endocrinol. 135, 129-138. doi: 10.1016/S0303-7207(97) 00195-0

Modi, M. E., Connor-Stroud, F., Landgraf, R., Young, L. J., and Parr, L. A. (2014). Aerosolized oxytocin increases cerebrospinal fluid oxytocin in rhesus macaques. Psychoneuroendocrinology 45, 49-57. doi: 10.1016/j.psyneuen.2014. 02.011

Mouillac, B., Chini, B., Balestre, M., Elands, J., Trumpp-Kallmeyer, S., Hoflack, J., et al. (1995). The binding site of neuropeptide vasopressin V1a receptor: evidence for a major localization within transmembrane regions. J. Biol. Chem. 270, 25771-25777. doi: 10.1074/jbc.270.43.25771

Muhlethaler, M., Sawyert, W. H., Manning, M. M., and Dreifuss, J. J. (1983). Characterization of a uterine-type oxytocin receptor in the rat hippocampus (electrophysiology/neurohypophyseal hormones/peptide analogues/structureactivity relationships). Proc. Nati. Acad. Sci. U.S.A. 80, 6713-6717.
Naghavi, M., Wang, H., Lozano, R., Davis, A., Liang, X., Zhou, M., et al. (2015). Global, regional, and national age-sex specific all-cause and cause-specific mortality for 240 causes of death, 1990-2013: a systematic analysis for the global burden of disease study 2013. Lancet 385, 117-171. doi: 10.1016/S01406736(14)61682-2

Nakamura, H., Itakuara, A., Okamura, M., Ito, M., Iwase, A., Nakanishi, Y., et al. (2000). Oxytocin stimulates the translocation of oxytocinase of human vascular endothelial cells via activation of oxytocin receptors. Endocrinology 141, 4481-4485. doi: 10.1210/endo.141.12.7832

Nation, D. A., Szeto, A., Mendez, A. J., Brooks, L. G., Zaias, J., Herderick, E. E., et al. (2010). Oxytocin attenuates atherosclerosis and adipose tissue inflammation in socially isolated ApoE-/- mice. Psychosom. Med. 72, 376-382. doi: 10.1097/PSY. 0b013e3181d74c48

Naylor, M., Bowen, K. K., Sailor, K. A., Dempsey, R. J., and Vemuganti, R. (2005). Preconditioning-induced ischemic tolerance stimulates growth factor expression and neurogenesis in adult rat hippocampus. Neurochem. Int. 47, 565-572. doi: 10.1016/j.neuint.2005.07.003

Nazari, A., Sadr, S. S., Faghihi, M., Azizi, Y., Hosseini, M. J., Mobarra, N., et al. (2015). Vasopressin attenuates ischemia-reperfusion injury via reduction of oxidative stress and inhibition of mitochondrial permeability transition pore opening in rat hearts. Eur. J. Pharmacol 760, 96-102. doi: 10.1016/j.ejphar.2015. 04.006

Nazari, M., Keshavarz, S., Rafati, A., Namavar, M. R., Haghani, M. (2016). Fingolimod (FTY720) improves hippocampal synaptic plasticity and memory deficit in rats following focal cerebral ischemia. Brain Res. Bull. 124, 95-102. doi: 10.1016/j.brainresbull.2016.04.004

Nilsson, U. (2009). Soothing music can increase oxytocin levels during bed rest after open-heart surgery: a randomised control trial. J. Clin. Nurs. 18, 21532161. doi: 10.1111/j.1365-2702.2008.02718.x

Ninan, I. (2011). Oxytocin suppresses basal glutamatergic transmission but facilitates activity-dependent synaptic potentiation in the medial prefrontal cortex. J. Neurochem. 119, 324-331. doi: 10.1111/j.1471-4159.2011.07430.x

Ohira, K., Takahiro, F., Hiroyuki, H., Kouichi, C. N., Eriko, K., Yasuyo, T., et al. (2010). Ischemia-induced neurogenesis of neocortical layer 1 progenitor cells. Nat. Neurosci. 13, 173-179. doi: 10.1038/nn.2473

Ohlstein, E. H., and Berkowitz, B. A. (1986). Human vascular vasopressin receptors: analysis with selective vasopressin receptor antagonists. J. Pharmacol. Exp. Ther. 239, 737-741.

Onodera, H., Aoki, H., Yae, T., and Kogure, K. (1990). Post-ischemic synaptic plasticity in the rat hippocampus after long-term survival: histochemical and autoradiographic study. Neuroscience 38, 125-136. doi: 10.1016/0306-4522(90) 90379-I

Ooboshi, H., Setsuro, I., Takashi, S., Yasuhiro, K., Junichi, T., Tetsuro, A., et al. (2005). Postischemic gene transfer of interleukin-10 protects against both focal and global brain ischemia. Circulation 111, 913-919. doi: 10.1161/01.CIR. 0000155622.68580.DC

Oppong-Damoah, A., Zaman, R. U., D’Souza, M. J., and Murnane, K. S. (2019). Nanoparticle encapsulation increases the brain penetrance and duration of action of intranasal oxytocin. Horm. Behav. 108, 20-29. doi: 10.1016/j.yhbeh. 2018.12.011

Oyama, H., Suzuki, Y., Satoh, S. I, Kajita, Y., Takayasu, M., Shibuya, M., et al. (1993). Role of nitric oxide in the cerebral vasodilatory responses to vasopressin and oxytocin in dogs. J. Cereb. Blood Flow Metab. 13, 285-290. doi: 10.1038/ jcbfm.1993.35

Pagani, J. H., Zhao, M., Cui, Z., Williams Avram, S. K., Caruana, D. A., Dudek, S. M., et al. (2015). Role of the vasopressin $1 \mathrm{~b}$ receptor in rodent aggressive behavior and synaptic plasticity in hippocampal area CA2. Mol. Psychiatry 20, 490-499. doi: 10.1038/mp.2014.47

Park, E. S., Jong, H. W., Kee, J. H., Suh, P. G., Sung, H. R., Hee, S. L., et al. (1998). Phospholipase C-Deltal and oxytocin receptor signalling: evidence of its role as an effector. Biochem. J. 331, 283-289.

Passoni, I., Leonzino, M., Gigliucci, V., Chini, B., and Busnelli, M. (2016). Carbetocin is a functional selective $\mathrm{Gq}$ agonist that does not promote oxytocin receptor recycling after inducing $\beta$-arrestin-independent internalisation. J. Neuroendocrinol. 28:n/a. doi: 10.1111/jne.12363

Petersson, M. (2002). Cardiovascular effects of oxytocin. Prog. Brain Res. 139, 281-288. doi: 10.1016/S0079-6123(02)39024-1 
Petersson, M., Alster, P., Lundeberg, T., and Uvnäs-Moberg, K. (1996). Oxytocin causes a long-term decrease of blood pressure in female and male rats. Physiol. Behav. 60, 1311-1315. doi: 10.1016/S0031-9384(96)00261-2

Petersson, M., Lundeberg, T., Sohlström, A., Wiberg, U., and Uvnäs-Moberg, K. (1998). Oxytocin increases the survival of musculocutaneous flaps. Naunyn Schmiedebergs Arch. Pharmacol. 357, 701-704. doi: 10.1007/PL00005227

Petersson, M., and Uvnäs-Moberg, K. (2008). Postnatal oxytocin treatment of spontaneously hypertensive male rats decreases blood pressure and body weight in adulthood. Neurosci. Lett. 440, 166-169. doi: 10.1016/j.neulet.2008. 05.091

Phaneuf, S., Asbóth, G., Carrasco, M. P., Europe-Finner, G. N., Saji, F., Kimura, T., et al. (1997). The desensitization of oxytocin receptors in human myometrial cells is accompanied by down-regulation of oxytocin receptor messenger RNA. J. Endocrinol. 154, 7-18.

Phie, J., Haleagrahara, N., Newton, P., Constantinoiu, C., Sarnyai, Z., Chilton, L., et al. (2015). Prolonged subcutaneous administration of oxytocin accelerates angiotensin II-induced hypertension and renal damage in male rats. PLoS One 10:e0138048. doi: 10.1371/journal.pone.0138048

Pierce, M. L., Mehrotra, S., Mustoe, A. C., French, J. A., and Murray, T. F. (2019). A comparison of the ability of leu8- and pro8-oxytocin to regulate intracellular $\mathrm{Ca} 2+$ and $\mathrm{Ca} 2+$-activated $\mathrm{K} 1$ channels at human and marmoset oxytocin receptors. Mol. Pharmacol. 95, 376-385. doi: 10.1124/mol.118.114744

Plested, C. P., and Bernal, A. L. (2001). Desensitisation of the oxytocin receptor and other g-protein coupled receptors in the human myometrium. Exp. Physiol. 86, 303-312.

Pietrogrande, G., Zalewska, K., Zhao, Z., Abdolhoseini, M., Chow, W. Z., SanchezBezanilla, S., et al. (2019). Low oxygen post conditioning prevents thalamic secondary neuronal loss caused by excitotoxicity after cortical stroke. Sci. Rep. 9:4841. doi: 10.1038/s41598-019-39493-8

Politowska, E., Kaźmierkiewicz, R., Wiegand, V., Fahrenholz, F., and Ciarkowski, J. (2001). Molecular modelling study of the role of cholesterol in the stimulation of the oxytocin receptor. Acta Biochim. Pol. 48, 83-93. doi: 10.18388/abp.2001_ 5114

Polshekan, M., Jamialahmadi, K., Khori, V., Alizadeh, A. M., Saeidi, M., Ghayour-Mobarhan, M., et al. (2016). RISK Pathway Is Involved in Oxytocin Postconditioning in Isolated Rat Heart. Peptides 86, 55-62. doi: 10.1016/j. peptides.2016.10.001

Postina, R., Kojro, E., and Fahrenholz, F. (1996). Separate agonist and peptide antagonist binding sites of the oxytocin receptor defined by their transfer into the V2 vasopressin receptor. J. Biol. Chem. 271, 31593-31601.

Poulain, D. A., and Wakerley, J. B. (1982). Electrophysiology of hypothalamic magnocellular neurones secreting oxytocin and vasopressin. Neuroscience 7 , 773-808. doi: 10.1016/0306-4522(82)90044-6

Rabow, S., Hjorth, U., Schönbeck, S., and Olofsson, P. (2018). Effects of oxytocin and anaesthesia on vascular tone in pregnant women: a randomised doubleblind placebo-controlled study using non-invasive pulse wave analysis. $B M C$ Pregnancy Childbirth 18:453. doi: 10.1186/s12884-018-2029-1

Rashed, L. A., Hashem, R. M., and Soliman, H. M. (2011). Oxytocin inhibits NADPH oxidase and p38 MAPK in cisplatin-induced nephrotoxicity. Biomed. Pharmacother. 65, 474-480. doi: 10.1016/j.biopha.2011.07.001

Ren, C., Gao, X., Niu, G., Yan, Z., Chen, X., and Zhao, H. (2008). Delayed postconditioning protects against focal ischemic brain injury in rats. PLoS One 3:e3851. doi: 10.1371/journal.pone.0003851

Richter, D. (1983). Synthesis, processing, and gene structure of vasopressin and oxytocin. Prog. Nucleic Acid Res. Mol. Biol. 30, 245-266. doi: 10.1016/S00796603(08)60688- 1

Rimoldi, V., Reversi, A., Taverna, E., Rosa, P., Francolini, M., Cassoni, P., et al. (2003). Oxytocin receptor elicits different EGFR/MAPK activation patterns depending on its localization in caveolin-1 enriched domains. Oncogene 22, 6054-6060. doi: 10.1038/sj.onc. 1206612

Ring, R. H., Schechter, L. L., Leonard, S. K., Dwyer, J. M., Platt, B. J., Graf, R., et al. (2010). Receptor and behavioral pharmacology of WAY-267464, a nonpeptide oxytocin receptor agonist. Neuropharmacology 58, 69-77. doi: 10.1016/ j.neuropharm.2009.07.016

Robinson, C., Schumann, R., Zhang, P., and Young, R. C. (2003). Oxytocininduced desensitization of the oxytocin receptor. Am. J. Obstet. Gynecol. 188, 497-502. doi: 10.1067/mob.2003.22
Rodrigo, R., Fernandez-Gajardo, R., Gutierrez, R., Matamala, J. S., Carrasco, R., Miranda-Merchak, A., et al. (2013). ). Oxidative stress and pathophysiology of ischemic stroke: novel therapeutic opportunities. CNS Neurol. Disord. Drug Targets 12, 698-714.

Roy, R. K., Augustine, R. A., Brown, C. H., and Schwenke, D. O. (2018). Activation of oxytocin neurons in the paraventricular nucleus drives cardiac sympathetic nerve activation following myocardial infarction in rats. Commun. Biol. 1:160. doi: 10.1038/s42003-018-0169-5

Di Scala-Guenot, D., and Strosser, M. T. (1992). Oxytocin receptors on cultured astroglial cells. regulation by a guanine-nucleotide-binding protein and effect of Mg2+. Biochem. J. 284, 499-505. doi: 10.1042/bj2840499

Schiffmann, A., and Gimpl, G. (2018). Sodium functions as a negative allosteric modulator of the oxytocin receptor. Biochim. Biophys. Acta 1860, 1301-1308. doi: 10.1016/j.bbamem.2018.03.003

Schmid, B., Wong, S., and Mitchell, B. F. (2001). Transcriptional regulation of oxytocin receptor by interleukin- $\beta$ and interleukin-6. Endocrinology 142, 1380-1385. doi: 10.1210/endo.142.4.8107

Seo, H. G., Lee, H. H., and Oh, B. (2018). The possible effect of oxytocin in postpartum recovery from a stroke: a case report. $P M R 10,1422-1425$. doi: 10.1016/j.pmrj.2018.04.005

Sharma, K., LeBlanc, R., Haque, M., Nishimori, K., Reid, M. M., and Teruyama, R. (2019). Sexually dimorphic oxytocin receptor-expressing neurons in the preoptic area of the mouse brain. PLoS One 14:e0219784. doi: 10.1371/journal. pone.0219784

Shear, M., Insel, P. A., Melmon, K. L., and Coffino, P. (1976). Agonist-specific refractoriness induced by isoproterenol. J. Biol. Chem. 251, 7572-7577.

Shenoy, S. K., and Lefkowitz, R. J. (2011). B-arrestin-mediated receptor trafficking and signal transduction. Trends Pharmacol. Sci. 32, 521-533. doi: 10.1016/j.tips. 2011.05.002

Shukla, V., Mishra, S. K., and Pant, H. C. (2011). Oxidative stress in neurodegeneration*. Adv. Pharmacol. Sci. 2011:572634. doi: 10.1155/2011/ 572634

Simpson, E. A., Paukner, A., Sclafani, V., Kaburu, S. S. K., Suomi, S. J., and Ferrari, P. F. (2017). Acute oxytocin improves memory and gaze following in male but not female nursery-reared infant macaques. Psychopharmacology 234, 497-506. doi: 10.1007/s00213-016-4480-x

Simsek, Y., Celik, O., Karaer, A., YÂlmaz, E., Gul, M., Ozerol, E., et al. (2012). Elevated cardiac oxidative stress in newborn rats from mothers treated with atosiban. Arch. Gynecol. Obstet. 285, 655-661. doi: 10.1007/s00404-0112069-5

Sirotkin, A. V., Schaeffer, H. J., Mlyncek, M., Miššik, J., and Bulla, J. (1996). Oxytocin affects the release of steroids, insulin-like growth factor-I, prostaglandin F2 $\alpha$ and cyclic nucleotides by human granulosa cells in vitro. Hum. Reprod. 11, 152-155. doi: 10.1093/oxfordjournals.humrep.a019009

Smith, M. P., Ayad, V. J., Mundell, S. J., McArdle, C. A., Kelly, E., and López Bernal, A. (2006). Internalization and desensitization of the oxytocin receptor is inhibited by dynamin and clathrin mutants in human embryonic kidney 293 cells. Mol. Endocrinol. 20, 379-388. doi: 10.1210/me.2005-0031

Soloff, M. S., Schroeder, B. T., Chakraborty, J., and Pearlmutter, A. F. (1977). Characterization of oxytocin receptors in the uterus and mammary gland. Fed. Proc. 36, 1861-1866.

Soloff, M. S., and Sweet, P. (1982). Oxytocin Inhibition of (Ca2 + + Mg2 +) -ATPase activity in rat myometrial plasma membranes. J. Biol. Chem. 257, 10687-10693.

Sriram, K., and Insel, P. A. (2018). GPCRs as targets for approved drugs: how many targets and how many drugs? Mol. Pharmacol. 93, 251-258. doi: 10.1124/mol. 117.111062

Staniæ, D., Pleæaš-Solaroviæ, B., Petroviæ, J., Bogavac-Stanojeviæ, N., Sopiæ, M., Kotur-Stevuljeviæ, J., et al. (2016). Hydrogen peroxide-induced oxidative damage in peripheral blood lymphocytes from rats chronically treated with corticosterone: the protective effect of oxytocin treatment. Chem. Biol. Interact 256, 134-141. doi: 10.1016/j.cbi.2016.07.006

Stary, C. M., Xu, L., Voloboueva, L. A., Alcántara-Hernández, M., Arvola, O. J., Idoyaga, J., et al. (2019). Nursing markedly protects postpartum mice from stroke: associated central and peripheral neuroimmune changes and a role for oxytocin. Front. Neurosci. 13:609. doi: 10.3389/fnins.2019.00609

Stoop, R. (2012). Neuromodulation by oxytocin and vasopressin. Neuron 76, 142-159. doi: 10.1016/j.neuron.2012.09.025 
Suzuki, Y., Satoh, S. I., Kimura, M., Oyama, H., Asano, T., Shibuya, M., et al. (1992). Effects of vasopressin and oxytocin on canine cerebral circulation in vivo. J. Neurosurg. 77, 424-431. doi: 10.3171/jns.1992.77.3.0424

Szeto, A., Nation, D. A., Mendez, A. J., Dominguez-Bendala, J., Brooks, L. G., Schneiderman, N., et al. (2008). Oxytocin attenuates NADPH-dependent superoxide activity and IL-6 secretion in macrophages and vascular cells. Am. J. Physiol. Endocrinol. Metab. 295, E1495-E1501. doi: 10.1152/ajpendo.90718. 2008

Szeto, A., Rossetti, M. A., Mendez, A. J., Noller, C. M., Herderick, E. E., Gonzales, J. A., et al. (2013). Oxytocin administration attenuates atherosclerosis and inflammation in watanabe heritable hyperlipidemic rabbits. Psychoneuroendocrinology 38, 685-693. doi: 10.1016/j.psyneuen.2012.08.009

Terrillon, S., Durroux, T., Mouillac, B., Breit, A., Ayoub, M. A., Taulan, M., et al. (2003). Oxytocin and vasopressin V1a and V2 receptors form constitutive homo- and heterodimers during biosynthesis. Mol. Endocrinol. 17, 677-691. doi: $10.1210 /$ me.2002-2222

Thibonnier, M., Berti-Mattera, L. N., Dulin, N., Conarty, D. M., and Mattera, R. (1999a). Signal transduction pathways of the human V1-vascular, V2-renal, V3pituitary vasopressin and oxytocin receptors. Prog. Brain Res. 119, 147-161. doi: 10.1016/S0079-6123(08)61568-X

Thibonnier, M., Conarty, D. M., Preston, J. A., Plesnicher, C. L., Dweik, R. A., and Erzurum, S. C. (1999b). Human vascular endothelial cells express oxytocin receptors. Endocrinology 140, 1301-1309.

Tiberiis, B. E., McLennan, H., and Wilson, N. (1983). Neurohypophysial peptides and the hippocampus. II. excitation of rat hippocampal neurones by oxytocin and vasopressin applied. Neuropeptides 4, 73-86. doi: 10.1016/0143-4179(83) 90011-2

Van Tol, H. H., Bolwerk, E. L., Liu, B., and Burbach, J. P. (1988). Oxytocin and vasopressin gene expression in the hypothalamo-neurohypophyseal system of the rat during the estrous cycle, pregnancy, and lactation. Endocrinology 122, 945-951.

Tom, N., and Assinder, S. J. (2010). Oxytocin in health and disease. Int. J. Biochem. Cell Biol. 42, 202-205. doi: 10.1016/j.biocel.2009.10.008

Tomizawa, K., Iga, N., Lu, Y. F., Moriwaki, A., Matsushita, M., Li, S. T., et al. (2003). Oxytocin improves long-lasting spatial memory during motherhood through MAP kinase cascade. Nat. Neurosci. 6, 384-390. doi: 10.1038/nn1023

Tuğtepe, H., şener, G., Biyikli, N. K., Yüksel, M., Çetinel, S., Gedik, N., et al. (2007). The protective effect of oxytocin on renal ischemia/reperfusion injury in rats. Regul. Pept. 140, 101-108. doi: 10.1016/j.regpep.2006.11.026

Tyzio, R., Cossart, R., Khalilov, I., Minlebaev, M., Hübner, C. A., Represa, A., et al. (2006). Maternal oxytocin triggers a transient inhibitory switch in GABA signaling in the fetal brain during delivery. Science 314, 1788-1792. doi: 10 . $1126 /$ science. 1133212

Uba, A. I., Radicella, C., Readmond, C., Scorese, N., Liao, S., Liu, H., et al. (2020). Binding of agonist WAY-267,464 and antagonist WAY-methylated to oxytocin receptor probed by all-atom molecular dynamics simulations. Life Sci. 252:117643. doi: $10.1016 /$ j.lfs.2020.117643

Uvnäs-Moberg, K. (1998). Oxytocin may mediate the benefits of positive social interaction and emotions. Psychoneuroendocrinology 23, 819-835. doi: 10.1016/ S0306-4530(98)00056-0

Vaidyanathan, R., and Hammock, E. A. D. (2017). Oxytocin receptor dynamics in the brain across development and species. Dev. Neurobiol. 77, 143-157. doi: 10.1002/dneu.22403

Viero, C., Shibuya, I., Kitamura, N., Verkhratsky, A., Fujihara, H., Katoh, A., et al. (2010). Oxytocin: crossing the bridge between basic science and pharmacotherapy. CNS Neurosci. Ther. 16:5, 138-156. doi: 10.1111/j.17555949.2010.00185.x

du Vigneaud, V., Ressler, C., and Trippett, S. (1953). The sequence of amino acids in oxytocin with a proposal for the structure of oxytocin. J. Biol. Chem. 205, 949-957.

Wang, M., Chen, J. T., Ruan, D. Y., and Xu, Y. Z. (2001). Vasopressin reverses aluminum-induced impairment of synaptic plasticity in the rat dentate gyrus in vivo. Brain Res. 899, 193-200. doi: 10.1016/S0006-8993(01) 02228-4

Wang, Y. F., and Hatton, G. I. (2009). Astrocytic plasticity and patterned oxytocin neuronal activity: dynamic interactions. J. Neurosci. 29, 1743-1754. doi: 10. 1523/JNEUROSCI.4669-08.2009

Wang, Y., Zhao, S., Liu, X., Zheng, Y., Li, L., and Meng, S. (2018). Oxytocin improves animal behaviors and ameliorates oxidative stress and inflammation in autistic mice. Biomed. Pharmacother. 107, 262-269. doi: 10.1016/j.biopha. 2018.07.148

Wautier, M. P., Guillausseau, P. J., and Wautier, J. L. (2017). Activation of the receptor for advanced glycation end products and consequences on health. Diabetes Metab. Syndr. 11, 305-309. doi: 10.1016/j.dsx.2016.09.009

Weber, J., Slemmer, J., Shacka, J., and Sweeney, M. (2008). Antioxidants and free radical scavengers for the treatment of stroke, traumatic brain injury and aging. Curr. Med. Chem 15, 404-414. doi: 10.2174/092986708783497337

Xu, F., Sun, S., Wang, X., Ni, E., Zhao, L., and Zhu, W. (2017). GRK2 mediates arginine vasopressin-induced interleukin- 6 production via nuclear factor-KB signaling neonatal rat cardiac fibroblast. Mol. Pharmacol. 92, 278-284. doi: 10.1124/mol.116.107698

Yamamoto, Y., Liang, M., Munesue, S., Deguchi, K., Harashima, A., Furuhara, K., et al. (2019). Vascular RAGE transports oxytocin into the brain to elicit its maternal bonding behaviour in mice. Commun. Biolo. 2:76. doi: 10.1038/ s42003-019-0325-6

Yashpal, K., Gauthier, S., and Henry, J. L. (1987). Oxytocin administered intrathecally preferentially increases heart rate rather than arterial pressure in the rat. J. Auton. Nerv. Syst. 20, 167-178. doi: 10.1016/0165-1838(87)90114-7

Young, L. J., Muns, S., Wang, Z., and Insel, T. R. (1997). Changes in oxytocin teceptor mRNA in rat brain during pregnancy and the effects of estrogen and interleukin-6. J. Neuroendocrinol. 9, 859-865. doi: 10.1046/j.1365-2826.1997. 00654.x

Young, L. J., Wang, Z., Donaldson, R., and Rissman, E. F. (1998). Estrogen receptor alpha is essential for induction of oxytocin receptor by estrogen. Neuroreport 9 , 933-936. doi: 10.1097/00001756-199803300-199803331

Yuan, L., Liu, S., Bai, X., Gao, Y., Liu, G., Wang, X., et al. (2016). Oxytocin inhibits lipopolysaccharide-induced inflammation in microglial cells and attenuates microglial activation in lipopolysaccharide-treated mice. J. Neuroinflamm. 13, 1-17. doi: 10.1186/s12974-016-0541-7

Zaman, R. U., Mulla, N. S., Gomes, K. B., D’Souza, C., Murnane, K. S., and D’Souza, M. J. (2018). Nanoparticle formulations that allow for sustained delivery and brain targeting of the neuropeptide oxytocin. Int. J. Pharm. 548, 698-706. doi: 10.1016/j.ijpharm.2018.07.043

Zatkova, M., Reichova, A., Bacova, Z., and Bakos, J. (2019). Activation of the oxytocin receptor modulates the expression of synaptic adhesion molecules in a cell-specific manner. J. Mol. Neurosci. 68, 171-180. doi: 10.1007/s12031-01901296-x

Zhang, L., Qu, Y., Yang, C., Tang, J., Zhang, X., Mao, M., et al. (2009). Signaling pathway involved in hypoxia-inducible factor- $1 \alpha$ regulation in hypoxicischemic cortical neurons in vitro. Neurosci. Lett. 461, 1-6. doi: 10.1016/j.neulet. 2009.03.091

Zhong, M., Navratil, A. M., Clay, C., and Sanborn, B. M. (2004). Residues in the hydrophilic face of putative helix 8 of oxytocin receptor are important for receptor function. Biochemistry 43, 3490-3498. doi: 10.1021/bi03 $5899 \mathrm{~m}$

Zhong, W., Yuan, Y., Gu, X., In-young, K. S., Chin, R., Loye, M., et al. (2020). Neuropsychological deficits chronically developed after focal ischemic stroke and beneficial effects of pharmacological hypothermia in the mouse. Aging Dis. 11, 1-16. doi: 10.14336/AD.2019.0507

Zhou, X. E., Yuanzheng, H., de Waal, P. W., Gao, X., Kang, Y., Van Eps, N., et al. (2017). Identification of phosphorylation codes for arrestin recruitment by g protein-coupled receptors. Cell 170, 457-469. doi: 10.1016/j.cell.2017. 07.002

Zingg, H. H. (1996). Vasopressin and oxytocin receptors. Baillières Clin. Endocrinol. Metab. 10, 75-96. doi: 10.1016/S0950-351X(96)80314-4

Zingg, H. H., and Laporte, S. A. (2003). The oxytocin receptor. Trends Endocrinol. Metab. 14, 222-227. doi: 10.1016/S1043-2760(03)00080-8

Conflict of Interest: The authors declare that the research was conducted in the absence of any commercial or financial relationships that could be construed as a potential conflict of interest.

Copyright (C) 2020 McKay and Counts. This is an open-access article distributed under the terms of the Creative Commons Attribution License (CC BY). The use, distribution or reproduction in other forums is permitted, provided the original author(s) and the copyright owner(s) are credited and that the original publication in this journal is cited, in accordance with accepted academic practice. No use, distribution or reproduction is permitted which does not comply with these terms. 